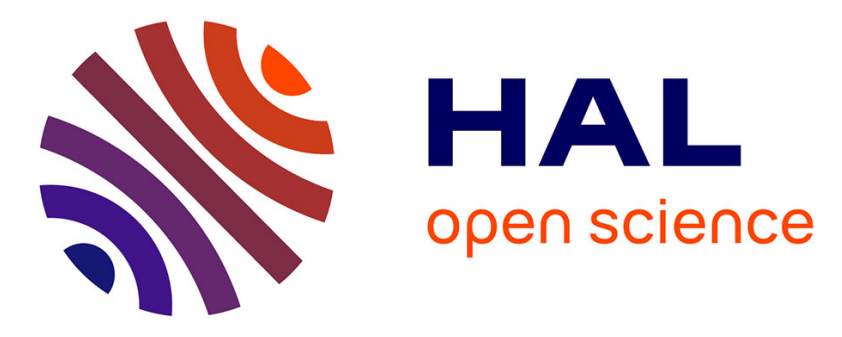

\title{
3D structural and thermal modelling of Mesozoic petroleum systems in the Po Valley Basin, northern Italy
}

Claudio Turrini, Barbara Bosica, Paul Ryan, Peter Shiner, Olivier Lacombe, Francois Roure

\section{To cite this version:}

Claudio Turrini, Barbara Bosica, Paul Ryan, Peter Shiner, Olivier Lacombe, et al.. 3D structural and thermal modelling of Mesozoic petroleum systems in the Po Valley Basin, northern Italy. Petroleum Geoscience, 2018, 24 (2), pp.172. 10.1144/petgeo2017-031 • hal-01630270

\section{HAL Id: hal-01630270 https://hal.sorbonne-universite.fr/hal-01630270}

Submitted on 7 Nov 2017

HAL is a multi-disciplinary open access archive for the deposit and dissemination of scientific research documents, whether they are published or not. The documents may come from teaching and research institutions in France or abroad, or from public or private research centers.
L'archive ouverte pluridisciplinaire HAL, est destinée au dépôt et à la diffusion de documents scientifiques de niveau recherche, publiés ou non, émanant des établissements d'enseignement et de recherche français ou étrangers, des laboratoires publics ou privés. 


\section{D structural and thermal modelling of Mesozoic} petroleum systems in the Po Valley basin, northern Italy

Claudio Turrini (1), Barbara Bosica (2), Paul Ryan (3), Peter Shiner (2), Olivier Lacombe (4), and François Roure $(5,6)$

\section{CTGeolConsulting, 78100, St.Germain-en-Laye, France (clturri@wanadoo.fr)}

2. Petroceltic Italia, Via E.Q: Visconti 20, Roma 00193, Italy

3. Petroceltic International plc, 3 Grand Canal Plaza, Grand Canal Street Upper, Dublin 4, Ireland

4. Sorbonne Universités, UPMC Univ Paris 06, CNRS, Institut des Sciences de la Terre de Paris (iSTeP), 4 place Jussieu 75005 Paris, France

5. IFP-EN, Rueil-Malmaison, France

6. Tectonic Group, Utrecht University, the Netherlands

\section{Abstract}

1D and 3D basin modelling was performed to investigate the Mesozoic carbonate petroleum systems of the Po Valley basin (northern Italy), through integration of a recent 3D structural model of the study area with the distribution of potential Triassic source rocks, rock property, and heat flow models.

Results from standard 1D maturity models show significant over-prediction of the thermal maturity of deep Triassic carbonates in the western Po Valley, unless the effect of the substantial overpressure observed in these sequences is incorporated into the model. In order to further test this observation, two thermal scenarios were applied to the Po Valley 3D geovolume: one based on the actual geological heat flow and a second model based on a reduced heat flow as a proxy for the delaying effect of overpressure on hydrocarbon maturation. The predictions of these two models were then compared with the observed hydrocarbon distribution in the western Po Valley.

Both thermal scenarios are broadly consistent with the observed hydrocarbon distribution at the scale of the basin, but in detail, the overpressure model provides a better match between the predicted charge available from the kitchen areas post-critical moment and 
observed volumes of hydrocarbons initially in place within the traps, as well as with the observed and predicted hydrocarbon phases, as measured by the gas/oil ratio (GOR) of the fluids. Overpressure probably significantly delayed hydrocarbon maturation in the western domain of the basin, confirming results from previous studies.

Beyond regional implications, and despite its relative simplicity and inherent uncertainties, the adopted approach demonstrates the potential of a consistent 3D integration of the thermo-structural history of sedimentary basins to constrain the geometry and structural evolution of hydrocarbon-bearing traps as well as the generation and migration of hydrocarbons into these traps.

Key-words: 3D thermo-structural models, thermal maturity, Po Valley tectonics and hydrocarbons, overpressure, Northern Italy

The Po Valley (Northern Italy) (Fig.1a) is the foreland-foredeep basin of the Southern Alps and the Northern Apennines thrust-belts and forms one of the best known hydrocarbon provinces in continental Europe (Errico et al., 1980; Pieri \& Groppi, 1981; Pieri, 1984; Cassano et al., 1986; Riva et al., 1986; Bongiorni, 1987; Mattavelli \& Novelli, 1987; Nardon et al., 1991; Mattavelli \& Margarucci, 1992; Mattavelli et al., 1993; Lindquist, 1999; Casero, 2004; Bertello et al., 2010). The basin stratigraphy consists of a thick $(4000-10000 \mathrm{~m})$ carbonate-clastic sedimentary section with both oil and gas having been produced from different levels across the basin. In this framework, the deep Mesozoic carbonates represent the preferential target for oil exploration whereas the overlying clastic intervals of Miocene, Pliocene and Pleistocene age are principally drilled for shallow gas accumulations.

Despite the long history of exploration-production activity and the progression of data and knowledge acqusition from both academia and industry, the thermal history of the Po Valley region has been poorly documented in the public literature (Wygrala, 1988; Chiaramonte \& Novelli, 1986), which has focused primarily on the temperature evolution of similar units cropping out in the adjacent Southern Alps fold-and-thrust units (Bersezio \& Bellantani, 1997; Greber et al., 1997; Calabrò et al., 2003; Fantoni \& Scotti, 2003; Scotti, 2005; Carminati et al., 2010).

In an attempt at gathering all available structural and stratigraphic datasets into a comprehensive view, Turrini et al. (2014) have produced a 3D structural model of the entire Po 
Valley basin. This model provides a spatially consistent structural geo-volume of the Po Valley, which allows better constraint of the influence of structural inheritance on the kinematic evolution of this foreland-foredeep system (Turrini et al., 2016) and better integration of the seismotectonics (Turrini et al, 2015).

As a further step toward a better understanding of the Po Valley hydrocarbon generation potential, we construct a regional, hydrocarbon-maturity-oriented structural and thermal model of the buried Mesozoic succession of the Po Valley. This approach relies upon the combination of our 3D structural model with a 1D and 3D thermal modelling of the entire Po Valley basin, with focus on the proven (Bertello et al., 2010) deep Mesozoic carbonates petroleum system. In particular, we aim to model and review the timing of trap formation across the Po Valley foreland-foredeep domain relative to the progressive maturation and generation history of the known Triassic source rocks. The possible impact of overpressure on hydrocarbon maturation is further addressed through thermal modelling considering both the actual geologic heat flow and a reduced heat flow aimed at approximating the delaying effects of overpressure on hydrocarbon maturation and generation. Beyond regional implications, this study demonstrates the utility and applicability of an integrated 3D basin modelling approach to better constrain the geometry and structural evolution of hydrocarbon-bearing traps in sedimentary basins as well as the generation and migration of hydrocarbons into these traps. Notably, the study confirms that the delaying effect of overpressure can be an important factor to be taken into account in predictions of hydrocarbon maturation and generation.

\section{The Po Valley basin}

\section{Regional geologic setting}

The geological architecture of the Po Valley basin has been discussed in many recent papers covering the different structural-stratigraphic aspects of the region (e.g., Turrini et al., 2014, 2015, 2016 and references therein).

The Po Valley basin is a complex basin system that developed as a nearly simultaneous pro/retro foreland-foredeep of the diachronous and opposite verging Northern Apennines and Southern Alps mountain belts. During Mesozoic and Cenozoic times, the Po Valley domain was affected by repeated extensional and compressional events (Fig.1b). These tectonic events essentially relate to the long-lasting geodynamic effects produced by Tethyan rifting and 
drifting, and subsequent oceanic subduction and collision of the Adria and Eurasian plates (Dewey et al., 1973; Castellarin, 2001; Carminati \& Doglioni, 2012; Pfiffner, 2014 and references therein). Indeed, the present-day structural pattern is primarily the result of Mesozoic extension and Cenozoic compression (Pieri \& Groppi, 1981; Bongiorni, 1987; Cassano et al., 1986; Castellarin et al., 1985; Fantoni et al., 2004, Ravaglia et al., 2006; Fantoni \& Franciosi, 2010; Turrini et al., 2014 and references therein). From Paleogene to present times, the amplification and propagation of the Northern Apennines and Southern Alps belts controlled the differential flexure of the Po Valley-Adria lithosphere, the associated tilting and bulging of the foreland domain, the rapid sedimentation of thick foredeep-type deposits and their successive involvement within the developing tectonic wedges (e.g., Carminati \& Doglioni, 2012 and references therein).

Mainly Miocene-to-Pleistocene thrusting is dominant across the shallow Tertiary sediments whereas a large part of the basin substratum (Mesozoic and basement) shows evidence of the pre-compressional tectonic grain, with autochthonous highs and lows of extension-related origin, partially reactivated by compression. Interference between the extension-related structures (approximately north-south trending) and the compression-related ones (generically west-east trending) is a primary characteristic within the basin (e.g., Turrini et al., 2016) which, given the earthquake distribution, is considered a more active tectonic province as one moves from west to east (Michetti et al., 2013; Vannoli et al., 2014; Turrini et al., 2015 and references therein).

The main stratigraphic units across the basin consist of Triassic platform carbonates, Jurassic to Cretaceous platform and basinal carbonates, overlain by Tertiary clastics (Fig.1c) (Jadoul, 1986; Cati et al., 1987; Jadoul et al., 1992; De Zanche et al., 2000; Ghielmi et al., 2012; Masetti et al., 2012; Pfiffner, 2014). This sedimentary package appears to overlie some Permian sediments and their Hercynian metamorphic basement (Fig.1c). The latter has been drilled by a few wells within the basin and locally crops out in the hinterland of the Southern Alps and the Northern Apennines (Cassano et al., 1986; Ponton, 2010; Pfiffner, 2014).

\section{Exploration history}

Exploration for hydrocarbons in the Po Valley started in the first half of the $20^{\text {th }}$ century (Pieri, 1984). Soon after the second world war, the investigations progressively covered the north-east of the basin while the use of electric well logs and cores, the development of updated 
micro-palaeontological techniques and, especially, the acquisition of analogue seismic data enabled the recognition and understanding of deeper targets. This resulted in the drilling of the Caviaga 1 well, (1944; 1404 m TD bsl - below sea level), the first gas field discovered by Agip within the Po Valley and the largest in Western Europe at that time. Between 1945 and 1982, the newly acquired digital seismic allowed the very deep horizons to be imaged, also favouring the development of new hypotheses concerning deep lithologies and their associated rock properties. In the 1980s, new methodologies led to the detailed analysis of the seismostratigraphy and the associated structural setting and style of the basin. The integration of well correlations with seismic interpretation resulted in the construction of the regional basePliocene structural map by Pieri \& Groppi (1981). From 1973 to 1984, hydrocarbon exploration of the Mesozoic carbonates developed through investigation of both overthrust structures developed during Alpine orogenesis and drilling of Mesozoic structural highs formed by Triassic-Liassic rifting (Bongiorni, 1987; Bertello et al., 2010). Both types of targets proved to be successful and led to the discovery of four major hydrocarbon fields, namely the Malossa (gas condensate), Cavone, Gaggiano and Villafortuna (oil) fields. The latter is one of the largest oil fields in continental Europe and has produced 226 million barrels (MMbbl) of light oil to date from a record depth of $6000 \mathrm{~m}$ bsl. Today the Po Valley stands as an under-explored region ready for the next exploration phase, with the help of exploitation of updated technologies integrated with increased knowledge of the basin geology.

\section{Hydrocarbon systems and hydrocarbon distribution}

Various petroleum systems have been identified and defined on the basis of drilling, outcrop geology and systematic analysis of the associated oil and gas types (Riva et al., 1986; Bongiorni, 1987; Mattavelli et al., 1993; Wygrala, 1988; Lindquist, 1999; Bello \& Fantoni, 2002; Franciosi \& Vignolo, 2002; Casero, 2004; Bertello et al., 2010).

The Triassic-Liassic petroleum systems have produced gas, condensate and light oil from deep Mesozoic carbonates (Fig.1c). The reservoir consists of dolomitized carbonate platform units of middle Triassic-Early Jurassic age, charged by middle to Late Triassic carbonate source rocks deposited in intra-platform lagoons and basins. Traps are mostly provided by Mesozoic extensional structures locally inverted during the Cenozoic compression. The Cretaceous-Jurassic pelagic carbonates provide the regional seal. The Villafortuna-Trecate Field (discovered in 1984; light oil; $226 \mathrm{MMbbl}$ of $43^{\circ}$ API oil and 93 billion of cubic feet (bcf) of gas produced to date), represents the largest oil accumulation associated with this play (Bello 
\& Fantoni 2002; Bertello et al., 2010). Second-order oil fields in terms of both size and production are the Malossa field (discovered in 1973; gas and condensate; approximately 27 MMbbl and 150 bcf gas produced) (Errico et al., 1980; Pieri \& Groppi, 1981; Mattavelli \& Margarucci, 1992), the Cavone field (discovered in 1974; 23API oil; $94.5 \mathrm{MMbbl}$ hydrocarbons initially in place HCIIP) (Nardon et al., 1991) and the Gaggiano field (discovered in 1982; 36 API oil; 20-30 MMbbl estimated reserves) (Bongiorni, 1987; Rigo 1991; Fantoni et al., 2004).

The Oligo-Miocene petroleum system (Fig.1c) produces thermogenic gas with secondary quantities of oil from the foredeep successions which are detached and thrust over the carbonates and belong to the Northern Apennine belt (Mattavelli \& Novelli, 1987, Mattavelli et al., 1993; Bertello et al., 2010). The system is composed of thick turbidite sequences that supply both the reservoir, source and seal elements and the traps are usually structural, with the Cortemaggiore and Casteggio fields as typical examples of producing fields related to this petroleum system.

The Plio-Pleistocene petroleum system contains large volumes of biogenic gas (Fig.1c), notably at the buried external fronts of the Apennine thrust belt (Mattavelli \& Novelli, 1987, Mattavelli et al., 1993; Lindquist, 1999; Casero, 2004; Bertello et al., 2010). The system consists of sand-rich turbidites in which thick-bedded sand lobes and thin-bedded, fine-grained basin plain/lobe fringe deposits are the main reservoir facies associations (Ghielmi et al. 2012). Interbedded clays are both the source-rock and the effective topseal. Traps are most commonly structural, yet stratigraphic traps also occur, mainly related to the onlap of turbidite reservoirs onto the flanks of thrust propagation folds or against the foreland ramp. The Settala field (1977) is a remarkable example of a mixed structural-stratigraphic trap in the Plio-Pleistocene play (Bertello et al., 2010).

The 3D basin model discussed in this paper specifically addresses the burial and temperature history of the thermogenic Mesozoic petroleum system. The Plio-Pleistocene and Oligo-Miocene systems are not discussed hereinafter.

\section{Methods, input data and modelling assumptions: building and calibrating the thermo- structural model of the Po Valley at the Mesozoic carbonate level}

Data used for the 3D structural model come from public literature and the archives of the Italian Ministry of Energy (http://unmig.sviluppoeconomico.gov.it, namely the ViDEPI project). These data include geological cross-sections, well composite logs as well as 
geophysical and geological maps. No seismic data have been used during the model building process because: a) they are poorly distributed across the study area, b) they are generally lowquality images, c) their integration into the model would have required a questionable timedepth conversion, uncertain due to simplifications in the estimated velocity distribution related to the widely varying lithologies in the study area. A full description of the whole dataset, and its distribution across the basin, is provided in Turrini et al. $(2014,2015,2016)$. The structural model was built using Midland Valley's MOVE software (http://www.mve.com/) while progressive refinement of the 3D grids and fault pattern was carried out using IHS's Kingdom interpretation package (https://www.ihs.com/products/kingdom-seismic-geologicalinterpretation-software.html).

The resulting Po Valley 3D structural model (Turrini et al., 2014, 2015) consists of 66 faults and 5 layer grids, namely: the Moho discontinuity, the basement, the near top Triassic, the top Mesozoic Carbonates, and the base Pliocene. At all levels within the model, the regionalscale architecture indicates the presence of two crustal domains, a western and an eastern domain separated by the Giudicarie Lineament, a NE-SW oriented feature dissecting the basin (Fig.2). Shallow structures are formed by folds and thrusts in the Tertiary clastic succession. Deep structures relate to faulting of the Mesozoic carbonates and their basement, with local inversion of pre-compressional basins and thin-skinned tectonic imbrication (Fig.3). The area of interest for the present study is strictly limited to the Northern Apennines and Southern Alps foreland domain in order to exclude major tectonic over-thickening across the Mesozoic structures that would have biased the thermal modelling results (see white stippled line in Fig.2).

Data used to populate the thermal model (back-stripping and thermal parameters, temperature and heat flow data, palaeo-water depths, total organic carbon - TOC -, hydrogen index - HI - values, etc.) are taken from published literature and publicly available well data (Riva et al., 1986; Mattavelli \& Novelli, 1987; Wygrala, 1988; Fantoni \& Scotti, 2003, ViDEPI Project) as well as a limited amount of proprietary data. Modelling was carried out using Zetaware Inc.'s Genesis \& Trinity 3D software packages (http://www.zetaware.com/) and proprietary spreadsheets.

The basin modelling workflow for this study consisted of three phases, described in detail in subsequent sections of this paper. The workflow is summarized in Table 1.

\section{Model structural geometries at the Mesozoic carbonate level}


The Villafortuna field, the Gaggiano field and the Lacchiarella structure, and the Malossa field are the most significant structures at the Mesozoic carbonate level which are considered in the thermal modelling. Despite being located outside the area covered by the thermal model, the Cavone structure is also described to complement the overall picture. Such structures a) illustrate the common deformation features affecting the Mesozoic carbonates in the Po Valley foreland, b) are related to the major tectonic events experienced in the region (Mesozoic extension and Cenozoic compression) and c) illustrate the main trap types for the deep Mesozoic oil play within the basin.

The Villafortuna field: The Villafortuna field (Figs. 2 and 3a, 4) corresponds to a major compressional structure that involves the Mesozoic section and the underlying basement (Pieri \& Groppi, 1981; Cassano et al., 1986; Bello and Fantoni, 2002; Turrini et al., 2014, 2016). The structure is weakly displaced towards the NW and wedges into the overlying Tertiary sediments, which, in turn, are thrust to the SE along the Romentino front (RF in Fig.4a, c, d). The base Pliocene unconformity separates the deformed Oligo-Miocene succession from the undeformed Plio-Pleistocene deposits. The field structure consists of a dome-type anticline, regionally plunging towards the SW and the NE (Fig.2 and 4a). Faults are SE and NW-dipping thrusts that cut down to the basement while controlling the gentle, final pop-up geometry below the Tertiary package (Fig.3 and 4c-d). Displacement is essentially towards the NW with an average throw of some $3 \mathrm{~km}$ at top carbonate level. In perspective and map view, the faults show an en-echelon pattern (Fig.4b). The presence of a complete late and middle Triassic reservoir-source section is reported within the field while a few hundred meters of Jurassicearly Cretaceous, basinal carbonates provide the likely topseal (Casero, 2004 and references therein; Bertello et al., 2010). According to the final 3D model, the trap area of the field is approximately $100 \mathrm{~km}^{2}$ and likely compartmentalized by Triassic-Jurassic normal faults (Casero, 2004 and references therein). These, given the lack of public information, could not be represented inside the structural model. The geometrical relationship between Tertiary sediments and the Mesozoic-basement assemblage within the Villafortuna tectonic wedge suggests that the age of the trap is mainly late Miocene (Turrini et al., 2016) with displacement of a pre-compressional Triassic high (Fig. 4c). 
The Gaggiano field and the Lacchiarella structure: The Gaggiano-Lacchiarella structure (Fig.5) is a crustal-scale tectonic feature which cuts across the entire Po Valley basin and extends towards the Southern Alps to the north and the Northern Apennines to the south (see Gaggiano location in Fig.2). This feature has a complex history: it initiated as a north-south striking, east-dipping extensional fault system in the Liassic, underwent initial inversion in the Oligocene and was weakly reactivated during the Miocene (Fantoni et al., 2004; Turrini et al., 2016). Liassic extension resulted in significant footwall erosion over the crest of the Gaggiano footwall high and in the deposition of an expanded section of deep-water Jurassic and Cretaceous carbonates in the subsiding Lacchiarella hangingwall basin. Oligocene inversion resulted in approximately no net extension at top Triassic level across the feature. Inversion and vertical expulsion of the thickened Jurassic-Cretaceous deep-water carbonate sediments, originally deposited in the Lachiarella hanging wall basin resulted in a regional north-south striking anticline immediately to the east of, and above, the trace of the extensional Liassic fault system (Fig.5). The structural framework derives from the overprinting of Mesozoic extensional and Tertiary compressional tectonics, as revealed by 2D sections through the model volume (see Fig.5c-e). Major faults in the region are east-dipping whereas the associated secondary faults are west-dipping, with the two fault sets bounding the Gaggiano high and the Lacchiarella basin. The Gaggiano field (Fig.3a and 5) is located on the west-dipping footwall crest of the north-south Triassic-Liassic extensional fault system (Cassano et al., 1986; Bongiorni, 1987; Fantoni et al., 2004; Turrini et al., 2014, 2016). Within the field, the Mesozoic section is extremely thinned by erosion associated with syn-extensional footwall uplift. basement is encountered by wells at the exceptionally shallow depths of approximately $5 \mathrm{~km}$ bsl (Fig. 5c-e). Based on the 3D model reconstruction, the top reservoir at Gaggiano lies just below the top Mesozoic surface, at an average depth of $4.5 \mathrm{~km}$ bsl, giving a closure of approximately $30 \mathrm{~km}^{2}$ and defining a relatively limited four-way-dip closure at the crest of the regional footwall (Bongiorni, 1987). This trap was formed by Liassic extension and underwent minor rotation during the Cenozoic, along with the deposition of Oligo-Miocene foredeep sediments. The top-seal is provided by intra-platform basinal carbonates (Meride formation), which also form the source rock for the field (Bongiorni, 1987; Bertello et al., 2010). Wells drilled on the Lacchiarella inversion structure (Lacchiarella-2 - 1978 - and San Genesio - 1994) have encountered significantly increased thicknesses of Jurassic and Cretaceous basinal limestones, confirming the overall tectono-stratigraphic model, but have failed to encounter significant hydrocarbons at the Triassic objective levels. 
299

300

301

302

303

304

305

306

307

308

309

310

311

312

313

314

315

316

317

318

319

320

321

322

323

324

325

326

327

328

329

The Malossa field : The Malossa field (Fig.3a - 6) is located in the western sector of the Milano tectonic arc (see Fig.2). The field is one of a number of structures which deform the Po Valley Mesozoic foreland and have been buried beneath the Tertiary foredeep wedges to the south of the Southern Alps belt (Errico et al., 1980; Pieri \& Groppi, 1981; Cassano et al., 1986; Mattavelli \& Margarucci, 1992; Fantoni \& Franciosi, 2010; Turrini et al., 2014). The reservoir of the field is provided by fractured late Triassic platform carbonates while the overlying Jurassic-Cretaceous basinal carbonates constitute the seal, along with some further reservoir sections. The source rock has not been proven within the field area. However, analysis of the oil (Mattavelli \& Novelli, 1987; Mattavelli \& Margarucci, 1992; Bertello et al., 2010) suggests a late Triassic source rock (Argilliti di Riva di Solto), a lithology which crops out extensively in the Southern Alps, to the north of the Malossa region (Fantoni \&Scotti, 2003). Stratigraphy from the well information indicates the presence of a Triassic-Liassic high. The trap is provided by a NW-SE oriented, faulted anticline, plunging towards both the NW and the SE. The associated major thrust is NE dipping and it displaces the structure towards the SW. Minor faults are reported to intersect the fold crest, creating structural compartments within the field (Mattavelli \& Margarucci, 1992). From the structural model, the average depth to the top Mesozoic structural crest is $5 \mathrm{~km}$ bsl, while the field area is approximately $15 \mathrm{~km}^{2}$ (Fig.6a). The final age of trap formation is mainly late Miocene with some minor reactivation during the PlioPleistocene (Turrini et al., 2016).

The 3D model (Fig.6) shows that the Malossa structure was formed byfolding and thrusting of the Mesozoic carbonates and the related basement. Sections through the model volume (Fig.6c-e) confirm that inversion of the Triassic-Liassic extensional basins controls the overall structural style in the region (Cassano et al., 1986; Ravaglia et al., 2006; Fantoni \& Franciosi, 2010; Masetti et al., 2012) with both reactivation of Mesozoic extensional faults and creation of new faults, which locally cut through the pre-existing highs. The Chiari and Belvedere structures, to the NE of the Malossa field are significant,.and together with the Lacchiarella structure (see section 4.1.2, Fig. 5), are the main evidence of the basin inversion that took place in the western Po Valley domain (cf. Figures 12 \& 13 in Turrini et al., 2016).

Key-characteristics of these two structures, as compared to Malossa are as follows: (a) the structures are inverted Liassic half-grabens and the thick $(5 \mathrm{~km})$ Mesozoic carbonates are vertically extruded by Miocene inversion (the Malossa structure is essentially a pre-existing 
Triassic-Liassic high deformed by Cenozoic thrusting); (b) the Mesozoic faults are reactivated (if the map shown by Mattavelli \& Margarucci, (1992) is considered correct, it is possible to argue that pre-compressional faults - not represented in the 3D model - are passively displaced by new thrusts in the Malossa structure); (c) some tectonic over-thickening of the Jurassic sediments can be interpreted from the public composite log (the Malossa well data does not appear to show any tectonic repetition); (d) the basement is involved in the structuration (as at Malossa); (e) the age of the present structural geometries is essentially late Miocene with some minor contribution from Pliocene tectonics (as at Malossa).

The Cavone field: The Cavone field (Fig.3b-7) is situated on the lateral ramp of a major tectonic arc (i.e. the Ferrara arc) at the buried front of the eastern Northern Apennines (see Fig.2) (Pieri \& Groppi, 1981; Cassano et al., 1986; Nardon et al., 1991; Turrini et al., 2014, 2016). The structure is a thrust-related fold where Mesozoic and Tertiary sediments are intensely faulted and fractured (Cassano et al., 1986; Nardon et al., 1991; Carannante et al., 2014). The age of the trap is essentially Plio-Pleistocene although Miocene tectonics might have contributed to the early stage development of the field (Castellarin et al., 1985; Nardon et al., 1991; Ghielmi et al., 2012; Turrini et al., 2016). The 3D structural model shows the imbrication of the Mesozoic units and the clear asymmetry of the associated thrust-related fold (see Fig.7): as such, faults inside the tectonic stack are mainly SSE dipping and the derived faulted anticline is NNW verging (Fig.7c). The observed vertical throw that separates the Cavone hanging-wall and foot-wall units (i.e. the Po Valley foreland) is around $1.5 \mathrm{~km}$ on average. The structural geometry described suggests a major detachment surface at the base of the Triassic sediments (arrow in Fig.7c \& d) and makes any involvement of the basement particularly unlikely (Cassano et al., 1986; Nardon et al., 1991) unless short-cutting and slicing of the footwall of the foreland unit has occurred (Carannante et al., 2014). The depth to the Cavone culmination from the available public data is approximately $3 \mathrm{~km}$ bsl, to near top Mesozoic and and $4 \mathrm{~km}$ bsl to top Triassic respectively. According to the reconstructed geometry, the field area would be in the order of $30 \mathrm{~km}^{2}$ (Fig.7a, c, d).

\section{Defining source rock distribution and building Gross Depositional Environment (GDE) maps} in the Mesozoic carbonates 
Middle and Late Triassic intervals (Fig. 8a) are the major source rocks for the deep Mesozoic petroleum system of the Po Valley (Mattavelli \& Novelli, 1987; Mattavelli et al., 1993; Zappaterra, 1994; Lindquist, 1999; Katz et al., 2000; Casero, 2004; Bertello et al., 2010). A description of the spatial distribution of these source intervals (Fig. 8b-c) and the assignation of the related main parameters describing hydrocarbon generation potential (net source thickness, TOC, HI etc.) (Table 1) are, as a consequence, key inputs for the basin modelling. The present section describes how the source model was constrained within the 3D basin model.

The definition of the source rock depositional setting and basin geometry across the Po Valley is a rather difficult task. Indeed: a) the tectonic history of the basin is complex and polyphased; b) only a few deep wells have drilled through the Triassic source intervals; c) mapping the lateral extent of the source rocks is not easy, given the lack of a clear seismic expression in the basins where the source rocks were deposited. Source rock distribution in the model is consequently described by the construction of Gross Depositional Environment maps (GDE maps) produced for key intervals.

Two loosely defined tectonically-controlled megasequences can be identified: a) a mainly middle Triassic (Anisian to late Carnian) megasequence, associated with extensionaltranstensional tectonics and local volcanism driven by plate scale wrench movements or aborted rifting; and b) a mainly late Triassic (late Carnian to early Liassic) megasequence, associated with Tethyan rifting. The middle Triassic megasequence (Fig. 8a) commences with the tectonic segmentation of the widespread epeiric carbonate-evaporitic platform system that dominated in the early Triassic. From the late Anisian onwards, intra-platform basins developed and euxinic conditions occurred periodically. This regional setting resulted in the deposition of organic-rich basinal carbonates over the entire Po Valley realm: the Meride limestone, the Besano and Gorno formations were deposited in the Western Po Valley whereas the Livinallongo formation, the bituminous events in the Predil Limestone and the Rio del Lago formation were deposited in the Eastern Po Valley. From the early Carnian onwards, subsidence slowed and platform carbonates prograded across the basins ending this first phase of deposition of organic-rich facies. The gross depositional environment map in Figure 8b shows the interpreted spatial distribution of potential source rock basins for this megasequence; in the western Po Valley, such basins are interpreted to have an approximately north-south orientation, whilst in the eastern Po Valley, the basins are interpreted as oriented north-east to south-west (Franciosi \& Vignolo, 2002). In the western Po valley, two potential source basins are identified: the Anisian to Ladinian Meride-Besano basin and the Carnian Gorno basin, situated to the west and east of 
Milan, respectively. The source potential of the former is confirmed by geochemical correlation with the oils from the Villafortuna-Trecate and Gaggiano fields (Bello \& Fantoni, 2002). The source rock potential of the Gorno basin is more speculative: the enrichment of organic matter is reported from outcrops (Stefani \& Burchill, 1990, Assereto et al, 1977, Wygrala, 1988) within sediments deposited in shallow anoxic lagoons developed within a mixed clastic-carbonate depositional system (Gnaccolini \& Jadoul, 1990). Nevertheless, little direct evidence exists for hydrocarbons having been generated in the subsurface from that formation. Indeed, extension of this facies southwards, into the subsurface of the Po Valley is exclusively based on the occurrence of an analogous facies in one of the wells within the Malossa field. In the Central Po Valley, along the buried Ferrara arc (i.e. the buried, external front of the Northern Apennines), the presence of a Mid Triassic source basin is inferred from the Cavone field oilsource correlation: this indicates a middle Triassic oil-prone carbonate source rock similar to the Meride Formation of the western Po Valley (Mattavelli \& Novelli, 1987; Nardon et al., 1991). In the eastern Po Valley and Adriatic foreland, the distribution of potential source basins is taken from Franciosi \& Vignolo (2002) with two offshore middle Triassic basins identified, the Ada and Amelia basins, as constrained by 3D seismic. However, the presence of source rock facies remains speculative. Onshore, organic-enriched middle Triassic (Anisian-Carnian) basinal marls and wackestones up to several tens of metres thick are known within the thick basinal successions of the Livinallongo, Predil, Rio del Lago and Durrenstein Formations of the south eastern Alps (Brack \& Rieber, 1993; Fantoni \& Scotti 2003; Keim et al 2006). Similar facies are encountered in the subsurface of the Po Valley at the Villaverla-1 well: these facies can be interpreted to lie within one of several north-east to south-west oriented basins, of similar dimensions to those mapped offshore on 3D seismic data (proto-Belluno trough, Masetti et al. 2012).

Extensional tectonics during the middle-late Norian in the Central Southern Alps and in the Carnian Pre-Alps resulted in the progressive segmentation of the widespread Dolomia Principale carbonate platform formed during late Carnian and early Norian quiescence. Extension developed approximately north-south oriented, intra-platform basins up to several tens of kilometres wide (Jadoul et al., 1992) which expanded as rifting progressed in the Liassic. Drowning of large sectors of the platform led to fully open marine deep-water conditions which were associated with the Tethyan-Ligurian Ocean. Eventually, restricted anoxic conditions developed during the Late Triassic. This resulted in the preservation of high levels of organic material within the basinal limestone facies, for example in the Argilliti di Riva di Solto, $\mathrm{Zu}$, and Aralalta formations in the Central Po Valley, and the Dolomia di Forni of the Eastern Po 
Valley. The GDE map in Figure 8c shows the interpreted spatial distribution of these potential source basins: the main basin in the western Po valley is the Riva di Solto basin of mid to late Norian age. This basin developed in the subsiding hanging wall of the major late TriassicLiassic Gaggiano-Lacchiarella extensional fault system (Fantoni \& Franciosi, 2010). Thinner sequences of organic-rich sediments were also deposited in a mid to outer ramp setting, in the overlying Rhaetian carbonate ramp represented by the Zu Formation (Stefani \& Burchill 1990, Galli et al 2007). The source potential of these successions is well documented both from outcrop (Jadoul et al., 1992) and geochemical typing of the oils from the Malossa field data (Mattavelli \& Novelli, 1987). In the eastern Po valley, the upper megasequence commences with a widespread late Carnian transgression, resulting in deposition of the organic-rich dolomites of the Monticello Formation, in an inner ramp setting. An organic-rich facies, about $60 \mathrm{~m}$ thick, ascribed to this interval is reported in the offshore Adriatic foreland at the Amanda1bis well (Carulli et al 1997). As transgression continued into the Norian, differentiation occurred in areas dominated by the widespread Dolomia Principale Platform, passing laterally into narrow ( $\mathrm{km}$ to a few tens of $\mathrm{km}$ ) anoxic basins. An example is the area of the future Belluno Trough where the organic rich Dolomia di Forni was deposited (Carulli et al 1997), locally attaining thicknesses of $850 \mathrm{~m}$. Within the Dolomia Principale, anoxic intra-platform lagoons developed locally and these are reported (Carulli et al 1997) onshore, in the eastern Southern Alps (over 100m of laminated dolomites and "scisti bituminosi" at Rio Resartico) and in the Adriatic offshore (the Amanda-1bis well).

The GDE maps (Fig.8b-8c) were used to define the lateral source rock distribution within the 3D basin model. Source parameters were then assigned to each polygon. The net thickness of source intervals is poorly constrained: the gross thickness of the source-bearing interval may locally reach $1 \mathrm{~km}$ inside the major depocentres (Pieri, 2001) whilst Fantoni et al. (2002) define $400 \mathrm{~m}$ of gross thickness for the Meride-Besano source interval in the Villafortuna-Trecate field. On this basis, net source thickness has been assigned with reference to the interpreted GDE, with a) long-lived anoxic basins assigned a net source thickness of 50m, b) episodically anoxic basins assigned $25 \mathrm{~m}$, and c) intra-platform/ ramp anoxic lagoons assigned $12.5 \mathrm{~m}$.

In general, potential source rocks are carbonate-argillaceous sediments with TOC varying from a maximum of $40 \%$ in the Besano Shales to a minimum of $0.10 \%$ within the Meride Limestone, with an average of $\sim 4 \%$ (Novelli et al., 1987, Fantoni et al., 2002, Katz et al, 2000). Kerogen types are dominantly of marine origin, with a secondary component of terrestrial material. For all source rocks within the model, those kerogen types have been 
parameterized as 90\% Type-A kerogen and 10\% Type-F kerogen, using default kinetic parameters as defined by Pepper \& Corvi (1995a-b) and as shown in Table 2. The only exceptions are the potential source rocks of the Gorno Formation which are described as dominantly consisting of reworked terrestrial material (Stefani \& Burchill, 1990) and have consequently been parameterized as 10\% Type-A kerogen and 90\% Type-F kerogen.

The petroleum potentials derived from these source parameters are reported in Table 2. They appear to be consistent with those reported in the literature: Fantoni et al (2002) suggest a formation average petroleum potential for the Meride-Besano interval at Villafortuna-Trecate of $21 \mathrm{~kg}$ of hydrocarbons per ton (HC/ton) of rock, whilst Bello \& Fantoni (2002) indicate a source potential index of $4 \mathrm{t}$ of hydrocarbons per square meter $\left(\mathrm{HC} / \mathrm{m}^{2}\right)$ (or 30 million barrels per square $\mathrm{km}-\mathrm{MMbbl} / \mathrm{km}^{2}$ ) for the mid Triassic petroleum system of the western Po Valley and of $3 \mathrm{t} \mathrm{HC} / \mathrm{m}^{2}$ (or $22 \mathrm{MMbbl} / \mathrm{km}^{2}$ ) for the Late Triassic petroleum system.

\section{Model rock physical properties}

The rock properties used as input for modelling include the following: 1) chrono-lithostratigraphy; 2) surface porosities; 3) compaction coefficients; 4) bulk densities; 5) radiogenic heat generation parameters for each lithology; 6) thermal conductivities and their temperature dependencies. These parameters were mainly derived from exploration wells or adjacent outcrop analogues (Berra \& Carminati, 2010, Pasquale et al 2011, Pasquale et al, 2012) (Table $3)$.

The chrono-litho-stratigraphic section used in the 1D modelling was built by assigning the percentages of end member lithologies present for each stratigraphic unit described (Fig 9a). Back-stripping and thermal properties were defined based on lithology. For mixed lithologies, properties are derived from the end member lithologies combined with the relative percentage of each using the appropriate mixing model: simple volumetric weighting is used to calculate surface porosity, compaction coefficient, density, volumetric heat capacity and radioactive heat generation, whilst thermal conductivities are calculated using a geometric mixing law (Pasquale et al. 2011). Temperature dependency of thermal conductivity is incorporated into the model using an approximation to the Sekiguchi Correction (Sekiguchi, 1984). A summary of the properties assigned for each end member lithology is given in Table 3. 
The Mesozoic carbonates of the western Po valley are characterized by high overpressures and these represent a significant challenge to deep exploration (Pietro et al., 1979; Vaghi et al., 1980). Early workers argued that formation pressure exerted a significant control on hydrocarbon maturation in the area, by illustrating a correlation of the possible overpressures with the difference between observed and theoretically calculated measures of maturity (Chiaramonte \&Novelli, 1986). While using a global dataset that included data points from the western Po Valley, subsequent investigations highlightedthe relationship between vitrinite reflectance and formation overpressure (Carr, 1999). This work resulted in a quantitative model based on modifying the Easy\%Ro algorithm of Sweeney \& Burnham (1990), which is based on the temperature history of a sample, to include an overpressure term. Following the emphasis placedby previous workers in the area on overpressure as a delaying factor on thermal maturity, one of the objectives of the present study was to investigate this effect and, should its importance be confirmed, incorporate it into the 3D basin modelling.

Novelli et al (1987) briefly reviewed the overpressure distribution in the western portion of the study area. This distribution is characterized by a normally pressured shallow clastic aquifer of Pliocene age and a deep, overpressured carbonate aquifer of Triassic age. This latter corresponds to the units that host the Triassic petroleum systems discussed in this paper. The two aquifers are separated by an aquitard consisting of fine-grained clastic rocks of Miocene to Paleogene age and fine-grained basinal carbonates of Paleogene to Jurassic age. This aquitard is characterized by a strong pressure ramp connecting the normally pressured shallow aquifer to the overpressured deep carbonate aquifer. These authors interpret overpressures as due to high sedimentation rates associated with foredeep sedimentation from the Oligocene onwards. Hydraulic isolation of the deep carbonate aquifer occurred during middle to late Miocene times due to Alpine thrusting, resulting in creation of the deep carbonate pressure cell, in the western Po Valley. Eventually, rapid burial during the Plio-Pleistocene produced the present distribution of overpressure within both the deep carbonate aquifer and the mixed clastic-carbonate aquitard.

In this study, the data and models presented by Novelli et al. (1987) were extended in two ways: a) by creating 1D pore pressure models for both the aquitard and the deep carbonate aquifer (for key wells), as an input to modelling the thermal maturity of organic matter; b) by reviewing the distribution of overpressures within the deep carbonate aquifer against the structure maps from the 3D model, while developing an understanding of the spatial and temporal distribution of these overpressures. 
The 1D pore pressure models for individual wells were built in two steps: firstly a constant overpressure was estimated for the deep carbonate aquifer, based either on pressure data from the well in question or from data presented by Novelli et al (1987) (their Fig. 7); secondly available pressure data (primarily mud-weight data, but with occasional well test or MDT data) in the aquitard were modelled using the Mann \& Mackenzie (1990) approach; in this process, the Plio-Pleistocene sedimentation rate was one key input whilst lithology within the aquitard and top overpressure were other key inputs (Mann \& Mackenzie, 1990). An example of such a model is shown in Fig. $9 \mathrm{~b}$ for the Belvedere well.

The 3D structural model clearly indicates that the overpressures are confined to a regional scale anticline developed at the Top Triassic level in the western Po valley (thick red line in Fig. 2), and that this anticline was in place by the end of the Miocene, although it probably formed sometime in the Paleogene (Turrini et al., 2016; see trap formation map in Figure 15). This anticline is isolated from the normally pressured carbonates of the eastern Po valley (e.g. the Malpaga-1 well; Novelli et al., 1987), across the Chiari syncline (Fig.2) which takes the Triassic sediments to a depth of 8-8.5 km bsl.

\section{Model water depths and heat flow}

Palaeo-water depths were inferred from a) the depositional facies locally defined at the different well locations and b) the GDE maps for key intervals (Fig.8b-c). These depths broadly correlate with those considered by Winterer \& Bosellini (1981) for the Mesozoic carbonates and by Di Giulio et al. (2013) and Ghielmi et al. (2012) for the Cenozoic. Finally, sedimentsurface interface and palaeo-temperatures are derived by combining palaeo-water surface temperatures based on the relative latitude of the Po Valley through time with a discrete water depth-temperature relationship such as that proposed by Defant (1961).

The heat flow model (Fig. 10) has been defined following a comparative review of published data, primarily from the Southern Alps (Mattavelli \& Novelli, 1987; Greber et al., 1997; Fantoni \& Scotti, 2003; Zattin et al., 2006; Scotti \& Fantoni, 2008; Carminati et al., 2010;

Grobe et al., 2015). There is general consensus around two episodes of increased heat flow during the Mesozoic: the first in the middle Triassic, caused by a first pulse of extensional tectonic activity, which resulted in the development of the basins where the middle Triassic source rocks were deposited; the second during the early Jurassic, associated with the full development of Tethyan rifting. A late Cenozoic reduction in the heat flow trend is observed due to high sedimentation rates and rapid burial in the foredeep, related to the advancing 
Southern Alps and Northern Apennine fronts. This is consistent with the basin geodynamics and associated tectono-stratigraphic evolution of the Po Valley region (see section 2.1). The present day heat flow has been estimated on the regional map of Italy of Della Vedova et al. (2001), with corrected well temperature data where available.

\section{Calibration of $1 D$ thermal model and assumptions underlying overpressure modelling}

A number of well locations, with available temperature and/or maturity data, were selected for 1D modelling to provide a reasonable geographic spread across the Po Valley region. Maturity data are mainly collected from the literature (particularly Wygrala, 1988; Chiaramonte \& Novelli, 1986; Fantoni \& Scotti, 2003) with the addition of some proprietary data. Furthermore, some pseudo-wells were constructed to fill in the areas where well data were sparse. The chrono- and litho-stratigraphy for each well were derived from the relevant composite log, with physical properties (porosity, density, thermal conductivity) being assigned based on lithology as described in section 3.3. Measured temperature data reported on the composite log were corrected to in-situ temperature using the approach described by Pasquale et al. (2012). In general, the available maturity data for the Mesozoic carbonates were limited and of poor quality, frequently showing substantial scatter. Much of the data consists of maximum Temperature (Tmax) values from Rock-Eval pyrolysis analysis. Those data were converted to vitrinite reflectance (\%Ro) equivalent values using the relationship of Jarvie et al. (2001). The satisfactory nature of this relationship in the study area was confirmed at wells with both Tmax and vitrinite reflectance data available.

As a first calibration step, the present-day temperature-depth relationship calculated from the model was compared with the corrected temperature values derived from the composite log. An example is the Belvedere-1 well (Fig. 9c). In general, the match between model and observation was acceptable particularly over the targeted carbonate section. Once a good match was obtained between temperature observations and predictions from the model, maturity profiles were calculated for each well and pseudo-well. Additionally, for wells with maturity data, the calculated profile was compared with observed data. As an example, Figure $9 \mathrm{~d}$ clearly indicates that the maturity profile calculated by the Easy \%Ro algorithm (which uses only the temperature history of each data point, Burnham \& Sweeney, 1989) for the Belvedere1 well, substantially over-predicts the observed thermal maturity: this is particularly true in the Mesozoic carbonates. In contrast, algorithms that incorporate the overpressure history, in addition to the temperature history, appear to produce a better fit to the observed data, with the 
PresRo algorithm of Carr (1999) producing very similar results to the alternative T-P-Ro algorithm of Zou \& Peng (2001). It is noteworthy that Carr,1999, incorporates overpressure effects into the Easy\%Ro model by introducing a pressure based modification to the frequency factor, whilst Zou \& Peng, 2001, introduce an overpressure based modification to the activation energies. For the purposes of this modelling exercise, it was assumed that pressures were hydrostatic up to the end Miocene isolation of the deep carbonate aquifer in the western Po valley. From the end of the Miocene onwards it was assumed that overpressures increased linearly with time up to the present day values modelled for a particular interval. As for the Belvedere 1, other wells included in the dataset showed similar results, with an improved fit to observed maturity data from models incorporating overpressure and over-prediction of maturity using Easy\%Ro. Of particular note at the Belvedere-1 well is the way in which the results of the overpressure algorithms converge with the Easy \%Ro model below 7,500m tvdss (Fig.9d). This is likely due to peak maturity deep within the carbonate section having been achieved during the Liassic rift event, long before significant overpressure entered the system. Such an early maturity was a consequence of the thick syn-rift section deposited at this location, combined with elevated heat flows. Notwithstanding the relatively poor quality and scattered nature of the maturity data, this analysis would appear to support the inference that overpressure has delayed the thermal maturity of the Triassic source rocks in parts of the Po Valley as suggested by Chiaramonte \& Novelli (1986) and Carr (1999).

The Genesis and Trinity 3D modelling software from Zetaware, Inc. used in this study does not incorporate algorithms that include the overpressure effect. The most appropriate modelling strategy was therefore to approximate the overpressure effect in the software by applying a reduced heat flow, given that overpressure appears to act to delay maturation (Carr, 1999). Figure 9d shows that the maturity profiles calculated for the Belvedere-1 well using the overpressure algorithms are approximated by a temperature-only maturity model using a heat flow that is $15 \mathrm{~m}$ watts per square meter $\left(\mathrm{W} / \mathrm{m}^{2}\right)$ lower than the currently observed heat flow at this location. Hence, to replicate the overpressure history in the basin, the reduced heat flow model was built to equal the geological heat flow up to the end of the Miocene. From that moment, the heat flow was varied linearly to reach a present day value that is $15 \mathrm{~mW} / \mathrm{m}^{2}$ lower than the observed present day heat flow. Similar results were obtained for other wells in the dataset. This analysis was also repeated for a number of pseudo-well data points covering the depth range of the Triassic source rocks within the model overpressure cell. This operation confirms that a reduced heat flow model satisfactorily replicates the maturity trends generated by the overpressure model. 


\section{Modeling results}

633

634

635

636

637

638

639

640

641

642

643

644

645

646

647

648

649

650

651

652

653

654

655

656

657

658

659

660

661

662

663

\section{$1 D$ thermal model and hydrocarbon generation}

The results from 1D modelling for well and pseudo-well locations in the western, central, east-central and eastern Po Valley are summarized in Figure 11. For the western and central Po Valley, two sets of results are provided, one based on the actual geological heat flow and one which considers the effect of overpressure through application of the reduced heat flow model from end Miocene times. In the western Po Valley, west of Milan (Fig. 11a), the Triassic source intervals reached maturity during the Miocene as a result of burial beneath the thick Alpine foredeep sediments. These source rocks are currently in the late oil window. In contrast, in the central Po Valley east of Milan (Fig. 11b), Triassic source rocks started generating hydrocarbons during the Jurassic, with renewed generation in the Miocene, and are currently in the late oil to gas windows. This generation process is probably due to the increased thickening of syn-rift Liassic carbonates in the hanging wall of the Gaggiano-Lacchiarella fault system, combined with high syn-rift heat flows. For both the western and central Po Valley well locations, the reduced heat flow / overpressure model shows lower maturity, all through PlioPleistocene. In the western Po Valley, this equates to the difference between middle oil maturity $(\% \mathrm{Ro} \approx 0.8)$ and wet gas maturity $(\% \mathrm{Ro} \approx 1.3)$.

Over most of the eastern Po Valley, middle Triassic source rocks attained early maturity during the Jurassic (Fig. 11c) due to thick carbonate deposition and high heat flows, with only minor increases in maturity to present day as a result of lower heat flow and/or a low sedimentary depositional rate. During the same time interval, Late Triassic source rocks remained immature to very early mature (Fig. 11c). Figure 11d shows the $1 \mathrm{D}$ model for part of the Trento Platform in the eastern Po Valley where sedimentation rates remained particularly low. In this location only limited generation potential isenvisaged, with the early oil window being reached by the middle Triassic source rocks in the late Miocene to Recent, whilst late Triassic source rocks are essentially immature at the present day.

\section{$3 D$ thermal model and hydrocarbon generation}

Results from 1D modelling (see above) and GDE maps have been integrated with the 3D structural model to create a 3D thermal model of the entire Po Valley foreland basin. Using 
the 1D well models as anchor points, two thermal histories were created and calibrated to best represent the thermal histories of the Middle and Late Triassic source intervals, one based on the actual geological heat flow model and one based on the reduced heat flow to replicate the effect of overpressure. In particular, the reduced heat flow associated with the overpressure model is confined to the area of the regional scale anticline at Top Triassic level that contains the overpressure cell, as shown in Fig. 2. Outside this area, the two heat flow models are equal. The progressive change in transformation ratio through time across the Po Valley for the middle and late Triassic source intervals from the Mesozoic to the end Miocene is illustrated in Figure 12. For middle Triassic source rocks early oil maturity is attained during the Jurassic to the east of the Gaggiano Lacchiarella fault system and in most of the eastern Po Valley whilst to the west maturity remains low (Fig 12a). This clearly fits the 1D modelling scenarios and confirms the results presented by Novelli et al., 1987.

The maturity pattern is attributed to high syn-rift heat flows associated with Liassic rifting, combined with the deposition of a) thick sequences of basinal limestones in the hangingwall of the Gaggiano Lacchiarella fault system, b) thick shallow marine carbonate deposits in the area of the Trento Platform (Fig. 2) and c) thinner basinal sequences to the west (footwall) of the Gaggiano Lacchiarella tectonic trend. Through the Cretaceous only small increases in maturity are observed due to low sedimentation rates in a deep-water, basinal setting. During this period, heat flows returned to typical passive margin setting levels (Fig. 12b) (Fantoni \& Scotti, 2003). Remarkably in Jurassic and Cretaceous times, the Late Triassic source rocks remain immature, except in the vicinity of locally thick carbonate deposits, particularly in the central and north-western Po Valley (Fig.12d-e).

During the early Tertiary and up to the end of the Miocene, the enhanced clastic influx from the Southern Alpine and Northern Apennines thrust belts increased burial of both Triassic source intervals with further increases in maturity. Locally, where sedimentation rates were highest, such as in portions of the Southern Alpine foredeep, this resulted in the completion of the kerogen transformation process (Fig 12c-f). Notwithstanding this, the Liassic structural grain continued to exert an influence on maturity patterns with much of the Gaggiano footwall and Trento Platform constantly exhibiting low maturities.

In middle to late Miocene times, the deep carbonate aquifer in the western Po Valley became isolated and the Triassic source intervals started to experience overpressure. Figure 13 compares the present-day transformation ratio distribution for the actual geological heat flow and reduced heat flow /overpressure models. The high Plio-Pleistocene sedimentation rate resulted in increased maturity throughout the Po valley, however, as expected, within the 
698

699

700

701

702

703

704

705

706

707

708

709

710

711

712

713

714

715

716

717

718

719

720

721

722

723

724

725

726

727

728

729

730

western Po Valley overpressure cell, the increase in maturity is substantially less for the overpressure model than for the geological heat flow model (compare Figs. 13a-c to Figs. 13bd). This effect is particularly evident over the crest of the Gaggiano footwall: the area shown in blue at end Miocene for both middle and late Triassic intervals (fig. 12c \& f), corresponding to a transformation ratio of less than $10 \%$, has completely disappeared at present day for the geological heat flow model (fig 13a-c), whilst for the overpressure model narrow belts with low transformation ratio remain over the crest of the footwall region (fig 13b-d).

Remarkably, both models show hydrocarbon generation occurring in two phases (Figs 11, 12, 13 \& 14): a Jurassic phase and an Alpine Tertiary phase, the latter starting in the Oligocene but occurring mainly during the last 5-10 million years, in agreement with earlier findings (Novelli et al., 1987; Mattavelli \& Novelli, 1987; Mattavelli et al., 1993; Lindquist, 1999; Bertello et al., 2010).

\section{Discussion}

\section{Overall validity of the thermo-structural modelling approach and choice of the better model}

3D charge modelling was carried out for a number of structures within the western Po valley overpressure cell in order to compare model predictions with observed hydrocarbon distribution and properties. Charge modelling was performed using the simple kinetic methodology described in Pepper \& Corvi (1995a, 1995b) and Pepper \& Todd (1995) as implemented in the Trinity Basin Modelling software. Source rock kerogen types and initial HIs and TOCs are shown in Table 2. For each structure, kitchen areas were defined as the areas of the present-day top Triassic depth map over which buoyancy forces would drain migrated hydrocarbons towards the relevant structural culmination. Those areas were then further refined by superimposing the source rock polygons from the GDE maps. Finally, the charge volumes for the various traps were then limited to those available after the critical moment, i.e., the time at which the trap formed or the seal became able to retain a hydrocarbon column (Fig. 14). The model also incorporates the effect of migration losses along the path to the trap, with considered loss of $0.075 \mathrm{MMbbl} / \mathrm{km}^{2}$, derived using the methodology proposed by Mackenzie \& Quigley (1988) with a bed thickness of 500m and an average porosity of $1.5 \%$. Reservoir and top-seal parameters are defined in order to allow the basin model to calculate volumes trapped in each structure. Here, a single late Triassic reservoir was modelled as a $250 \mathrm{~m}$ thick, $100 \%$ net-togross slab with an average porosity of 3\% (see Bello \& Fantoni, 2002 for comparison). Top- 
seal capacity was modelled as 300 pounds per square inch (psi) using simple capillary seal models for pelagic carbonates. The basin model has been re-run, and the following predicted parameters were extracted: volume of charge available from the relevant kitchen area since the critical moment, trapped hydrocarbon volume and gas/oil ratio (GOR) of the trapped fluids.

These predicted parameters compare well with estimates of the initially in place hydrocarbon volume (HCIIP) at each trap and for the GOR of the fluids present in the three main discoveries in the western Po valley (Fig.15) : to a first order, both the actual geological heat flow and the reduced heat flow / overpressure models replicate accurately the overall distribution and phase of hydrocarbons and predict significant discoveries at VillafortunaTrecate and Malossa and a smaller discovery at Gaggiano. They also predict a rich petroleum system with significant volumes of hydrocarbons spilled from traps that have been breached, bypassed and/or overfilled. This is evident at Gaggiano where the two models equally calculate small trapped volumes due to the size of the trap. Indeed, being located at the crest of a regional high (see Figs.2 and 3a), the Gaggiano trap appears to be linked to an extensive kitchen area, which, since the Mid-Miocene critical moment, has generated charge volumes 25 to 50 times larger than the trapped volumes. Finally, the two models predict liquid hydrocarbons with moderate-to-low GOR at Villafortuna-Trecate and Gaggiano whilst high GOR fluids are predicted at Malossa.

As a result, despite the relative simplicity of the modelling approach adopted and uncertainties regarding source rock distribution, our 3D thermo-structural modelling provides for the first time a consistent integration of the 3D structures with their thermal histories and reliably simulates the related hydrocarbon maturation/generation process across the entire Po Valley basin.

In detail however, the reduced heat flow / overpressure model better matches the observed data than the actual geological heat flow model. In this respect, Figure 15a compares calculated trap HCIIP volumes with the predicted charge available from the kitchen area since the critical moment. The graph shows that predictions from the overpressure model (excluding Gaggiano) correlate better with trap HCIIP values than those from the actual geological heat flow model. Also, the overpressure model can successfully explain the failures in the inversion traps in the Lacchiarella hangingwall (Lacchiarella and San Genesio) and the deep traps east of Malossa (Chiari, Belvedere). Conversely, the actual geological heat flow model predicts significant volumes in several of these traps. Furthermore, charge volumes available to the trap are closer to HCIIP volumes for the overpressure model than for the actual geological heat flow 
model. This implies that smaller volumes are spilled to shallower traps and/ or stratigraphic levels. Given little evidence for large spilled volumes in the Po Valley, the prediction of smaller excess volumes favours the overpressure model.

Figure $15 \mathrm{~b}$ shows how predicted trap volumes from the basin models compare with the calculated trap HCIIP volumes. Given that traps are generally oversupplied with hydrocarbons in both models, there is relatively little difference in the performance of the two models. However, it is of note that Malossa volumes are matched better by the overpressure model as there is a charge limitation on predicted volumes in the trap; the actual geological heat flow model predicts larger volumes with the trap being oversupplied and excess volumes spilled. Finally, Figure 15c shows that the overpressure model more successfully predicts fluid phase than the actual geological heat flow model, which predicts higher maturity fluids with higher GORs than observed for all three of the main discoveries.

We therefore conclude that overpressure as simulated by a reduced heat flow is a viable and valid mechanism that has likely significantly delayed hydrocarbon maturation in the western Po valley, as proposed by earlier authors (Chiaramonte \& Novelli, 1986, Carr, 1999).

\section{Uncertainties on the modelling results and sensitivity}

Structural model uncertainties: The Po Valley 3D structural model (Turrini et al., 2014) defines the present-day configuration and geometrical framework of the basin. Although a regional scale kinematic restoration to pre-Alpine and/or Mesozoic position has been recently attempted (Turrini et al., 2016), the chosen modelling approach applied here to the evolution of the Mesozoic petroleum system is a conventional one. Although a 2D kinematic approach would have beena more accurate methodology for modeling such a complex petroleum system (Gusterhuber et al., 2014; Neumaier et al., 2014), simple vertical back-stripping was carried out to describe the tectono-stratigraphic evolution of the basin. Despite this simplification, we believe the modelling results are reasonable due to the following considerations.

The model has been restricted to the foreland domain, characterized by low deformation and in which vertical displacements are more significant than horizontal ones (Cassano et al., 1986; Turrini et al., 2014). Locally, thrust faults can create a late tectonic over-thickening of the thrust section, particularly where a hangingwall ramp is juxtaposed with a footwall ramp. An example is provided by the Medolo Formation in the Belvedere well, where an estimated $500 \mathrm{~m}$ of tectonic thickening occurs on a Miocene thrust fault. This is incorporated into the model as stratigraphic thickening of the Medolo sediments and contributes to the high 
transformation ratio in the vicinity of the Belvedere well shown at end Jurassic times (Figs 12a and d). However, sensitivity modelling indicates that the effect is minor and local, given the relatively small scale of the thrusting involved, and does not impact the validity of the regional results presented.

The vertical back-stripping approach used approximately describes the recent evolution of the system, and covers the bulk of hydrocarbons generated during the Alpine phase. The model will not adequately describe generation and expulsion of hydrocarbons during the earlier Jurassic phase as trap distribution and geometry were substantially different during this phase. However, the effective charge in both models has been limited to post-critical moment, which took place sometimes in the Miocene. Consequently, hydrocarbons generated earlier are lost to the system and deemed to have leaked to the surface. Therefore, the lack of structural restoration does not impact the results, although any possible re-migration from reactivated Mesozoic traps has not been considered.

A further simplification in the model is that all surfaces other than the base Pliocene surface have been modelled as conformities. A number of erosional unconformities earlier in the Tertiary have been neglected, due to insufficient data to simulate these at the regional scale of the model. The literature on the region (Pieri \& Groppi, 1981; Cassano et al., 1986; Ghielmi et al., 2012; Rossi et al., 2015) suggests that: a) erosion of Mesozoic sediments was essentially restricted to locally uplifted areas, such as the syn-rift footwall erosion experienced over the crest of the Gaggiano footwall and b) erosion of Tertiary deposits associated with intra-Tertiary unconformities is in the order of few hundred metres. Consequently, given limited pre-Pliocene erosion and high Pliocene-Pleistocene sedimentation rates, it is likely that Mesozoic source rocks are at maximum depth of burial and peak thermal maturity at the present day across the vast majority of the basin (Ghielmi et al., 2012; Rossi et al., 2015). Given the limited and local nature of the pre-Pliocene unconformities, it is considered unlikely that their absence from the model significantly affects results, although it may result in some local errors in the maturation history.

Petroleum systems uncertainties: The main uncertainty pertaining to petroleum systems consists of the source rock distribution (position and areal extent of the source polygons of Fig. $8 \mathrm{~b}$ and $\mathrm{c}$ ) defined on the basis of the GDE maps. A second major uncertainty refers to the assigned net source thicknesses, essentially due to paucity of the available input data. Indeed, 
the models mainly rely on outcrop information from the Southern Alps and it should be noted that the South Alpine Front, which separates the outcrops from the subsurface of the Po Valley, is a Tertiary feature with an estimated 50-70 km of shortening (e.g., Handy et al., 2014). In this framework, considerable uncertainty exists in correlating from the outcrop to the subsurface.Furthermore, the source rock distribution defined here includes a number of postulated source basins, particularly in the eastern Po Valley and the Adriatic offshore. Another potential issue arises in the interpretation of the unsuccessful wells in the western Po Valley.

The ability to explain these failures as due to lack of access to recent charge was used as a reason for preferring the reduced heat flow / overpressure model to the actual geological heat flow model (the latter predicting the availability of significant recent charge volumes to these traps). Clearly there is a range of other potential failure mechanisms unrelated to source rock that could explain these well results.

Sensitivity to thermal and burial history parameters: The basin modelling presented here derives from a long and continuous analysis of sensitivities for the many parameters which control the burial and thermal history of the Po Valley region.

Heat flow based on data from the available literature (see Fig.10) was chosen as the key element to replicate the overpressure effect. Reducing the heat flow is a straightforward method to control the vitrinite maturation progression around the basin. In addition, using heat flow as a key controlling factor on hydrocarbon maturation can be used as stand-alone tool which does not directly impact the various parameters which affect the simulation process (e.g. rock properties, burial history, source distribution). Quality control (QC) on the heat flow history was concentrated on both past and present history to best match the vitrinite profile available at selected well locations in the Po Valley. In particular, in order to build the reduced heat flow / overpressure model particular attention has been paid to the reconstruction of the Miocene-PlioPleistocene curve segment. This needed to be viable with respect to the tectono-stratigraphic history of the basin where rapid sedimentation of the clastic succession was associated with localized overpressure build-up in the Mesozoic carbonates. The radiogenic heat flow component possibly derived from mineral associations of the Tertiary sediment has also been evaluated although it was finally considered irrelevant to the basin model results.

Notwithstanding the key role of the Po Valley heat flow on the study objectives, all of the basin model parameters (see Table 2) have been progressively evaluated and implemented 
from the initial Genesis/Trinity software standard values. Again, the primary aim was to refine the match with the available maturity data while keeping a present-day heat flow consistent with the published one. In particular: a) lithologies have been refined on the basis of a careful analysis of the well logs; b) matrix thermal conductivity of the sediments, especially for shales and sandstones, have been reviewed in the light of the available literature; c) for specific rock types such as silts and conglomerates, surface porosity, compaction coefficient, porosity and bulk density have been adjusted using literature data while iteratively validating the model constraints (i.e. well temperatures and vitrinite profiles); d) porosity in the Mesozoic carbonates was also validated against the field values as it was considered the main variable in the computation of migration losses in the model versus observed hydrocarbon production analysis.

Further sensitivity tests were performed on progressive sea level paleodepth variations, an important factor on sea level temperature at the different stages of the burial-thermal history. Indeed, almost all of the decrease in water-sediment interface temperature occurs in the first hundred metresso that anomalously shallow paleodepth estimates can cause $10^{\circ} \mathrm{C}$ excess temperature at the source rock level through part of the geological burial history. This would then require an unrealistic reduction in the heat flow in order to match the vitrinite data constraining the basin model.

Finally, the properties and parameters which have been used and progressively implemented during the model building are strictly interrelated. Sensitivity analyses demonstrated how changing one parameter often results in a compensatory change to another parameter. Their implementation, coupled with heat flow adjustment had a significant impact on the final model results.

Implications for the thermo-structural evolution of the Po basin and hydrocarbon generation and prospectivity

The 3D basin model of the Po Valley presented in this paper provides important insights into the geometry and structural evolution of hydrocarbon-bearing traps, and into the generation and migration of hydrocarbons into these traps.

The model confirms earlier studies (Novelli et al., 1987; Mattavelli \& Novelli, 1987; Mattavelli et al., 1993; Lindquist, 1999; Bertello et al., 2010) and shows that hydrocarbon generation likely occurred in two phases: a Jurassic phase and an Alpine Tertiary phase, the latter occurring mainly during the last 5-10 million years. Our results emphasize the impact that 
Mesozoic and Tertiary Alpine tectonics had on the development of a successful petroleum system in the Po valley. The Mesozoic extensional phase controlled reservoir and source distribution, trap formation (e.g. Gaggiano oil field) and the early phases of hydrocarbon maturation in subsiding half grabens associated with high heat flows and substantial syn-to early-post-rift sediment accumulation. The Tertiary compressional phase controlled trap formation, either by generating new traps (Cavone oil field) or by reactivating older ones inherited from the Mesozoic extensional phase (Villafortuna-Trecate, Malossa oil fields). Clearly, regional hydrocarbon maturation and expulsion/migration are related to rapid foredeep burial ahead of the evolving southern Alpine and northern Apenninic thrust belts.

From a hydrocarbon exploration point of view, the timing of hydrocarbon maturation is favourable for exploration in the western Po Valley. Trap formation is likely to have occurred during the Oligocene to late Miocene, along with significant post-Miocene hydrocarbon generation and expulsion (migration?). In contrast, in the eastern Po Valley, timing is less favourable as traps - Plio-Pleistocene in age - tend to either post-date the main hydrocarbon generation phase, or they formed when generation was not advanced enough for migration to occur, or for traps to be filled.

\section{Conclusions}

Using the recent Po Valley 3D structural model as an input for basin modelling, the approach presentedin this contribution provides for the first time a unique integration of the 3D structures with their thermal history and the related hydrocarbon maturation/generation process across the entire Po Valley basin.

When compared with the observed distribution of hydrocarbons, our basin modelling results suggest that, at the regional scale, both maturity models (actual geological heat flow model and reduced heat flow-overpressure model designed to simulate the delaying effect of overpressure on hydrocarbon generation) appear consistent with the observed hydrocarbon distribution. In detail however, the overpressure model a) provides an improved match to observed maturity data, b) provides a better fit between calculated trap HCIIP volumes and predicted charge available from the kitchen area since the critical moment and c) predicts hydrocarbon phase (as measured by GOR) more accurately than the geological heat flow model. However caution should be applied to the different variables and uncertainties which pertain to the accumulation process (i.e. source rock net pay, expelled versus un-movable hydrocarbons, heterogeneity in the TOC content of the source intervals, reservoir net volume and associated 
heterogeneity, and quantitative estimates of migration losses). The modelling results confirm that the delaying effect of overpressure is an important factor to be taken into account in predictions of hydrocarbon maturation and generation.

The study also confirms the impact that Mesozoic and Tertiary Alpine tectonics had on the development of a successful petroleum system in the Po valley. The Mesozoic extensional phase controlled reservoir and source distribution, trap formation and the early phases of hydrocarbon maturation in subsiding half grabens associated with high heat flows and substantial syn-to early-post-rift sediment accumulation. The Tertiary compressional phase controlled trap formation, either by generating new traps or by reactivating older ones inherited from the Mesozoic extension.

This study demonstrates the utility and applicability of a consistent integrated 3D model of the thermo-structural history of sedimentary basins to constrain the geometry and structural evolution of hydrocarbon-bearing traps as well as the generation and migration of hydrocarbons into these traps.

\section{Acknowledgements}

Roberto Fantoni from ENI S.p.a. is kindly acknowledged for discussion about some parts of the manuscript. We thank Jo Prigmore, Tim Diggs and Ozkan Huvaz for their constructive comments on the manuscript.

\section{References}

Andreatta, C., Dal Piaz, G., Vardabasso, S., Fabiani, R., Dal Piaz, G., 1957. Carta geologica delle Tre Venezie, scale 1:100,000, Map "10-Bolzano".

Assereto, R., Jadoul, F., Omenetto, P., 1977. Stratigrafia e metallogenesi del settore occidentale del distretto a $\mathrm{Pb}, \mathrm{Zn}$, fluorite e barite di Gorno (Alpi bergamasche) - Riv. Ital. Paleont., 83, 3, 395-532.

Bello. M., Fantoni, R., 2002. Deep oil plays in the Po Valley: Deformation and hydrocarbon generation in a deformed foreland - AAPG HEDBERG CONFERENCE, "Deformation History, Fluid Flow Reconstruction and Reservoir Appraisal in Foreland Fold and Thrust Belts" May 14-18, 2002, Palermo - Mondello (Sicily, Italy).

Berra, F., Carminati, E., 2010. Subsidence history from a backstripping analysis of the PermoMesozoic succession of the Central Southern Alps (Northern Italy). Basin Research, 22, 952975. 
Berra F., Galli M.T., Reghellin F., Torricelli S., Fantoni R., 2009. Stratigraphic evolution of the Triassic-Jurassic succession in the Western Southern Alps (Italy) : the record of the two-stage rifting on the distal passive margin of Adria-Basin Research, 21, 335-353.

Bersezio, R. \& Bellantani, G., 1997. The thermal maturity of the Southalpine mesozoic succession north of Bergamo by vitrinite reflectance data. Atti Tic.Sc.Terra, 5, 101-114.

Bertello. F., Fantoni, R., Franciosi, R., Gatti, V, Ghielmi, M., Pugliese, A., 2010. From thrustand-fold belt to foreland: hydrocarbon occurrences in Italy. VINING, B.A. \& PICKERING, S. C. (eds) Petroleum Geology: From Mature Basins to New Frontiers - Proceedings of the 7th Petroleum Geology Conference, 113-126. DOI: 10.1144/0070113 \# Petroleum Geology Conferences Ltd. Published by the Geological Society, London.

Bertotti G., Picotti V., Bernoulli D., Castellarin A.,1993. From rifting to drifting: tectonic evolution of the South-Alpine upper crust from the Triassic to the Early Cretaceous Sedimentary Geology, 86, 53-76.

Bongiorni, D., 1987. La ricerca di idrocarburi negli alti strutturali mesozoici della Pianura Padana: l'esempio di Gaggiano - Atti Tic. Sc. Terra Vol. XXXI, pp. 125-141.

Brack, P., Rieber, H., 1993. Towards a better definition of the Anisian/Ladinian boundary : New biostratigraphic data and correlations of boundary sections from the Southern Alps. Eclogae geol. Helv. 86/2: 415-527. (FINE BY ME)

Braga, Gp., Castellarin, A., Corsi, M., De Vecchi, Gp., Gatto, Gino., Gatti, Giuseppe, Largaiolli, T., Monese, A., Mozzi, G., Rui, A., Sassi, F.P., Zirpoli, G., 1968. Carta Geologica D’Italia, scale 1:100,000, Map “36-Schio”.

Burnham, A.K., and Sweeney, J.J., 1989, A chemical kinetic model of vitrinite maturation and reflectance: Geochimica et Cosmochimica Acta, v. 53, p. 2649-2657.

Calabrò R., Ceriani A., Di Giulio A., Fantoni R., F. Lino, Scotti P, 2003. Thermal history of syn-rift successions between the Iseo Basin and the Trento Plateau: results from the integrated study of organic matter maturity and fluid inclusions. Atti Tic. Sc. Terra, serie sp. v. 9, pp. 8891.

Cantelli, C., Carloni, G.C., Castellarin, A., Ceretti, E., Colantoni, P., Cremonini, G., Elmi, C., Frascari, F., Monesi, F., Pisa, G., Rabbi, E., Tomadin, L., Vai, G.B., Braga, Gp., Corsi, M., Gatto, G., Locatelli, D., Rui, A., Sassi, P., Zirpoli, G., Dal Cin, R., Largaiolli, T., Gatto, G.O., 1971. Carta Geologica D’Italia, scale 1:100 000, Map “4C-13- Monte Cavallino-Ampezzo”.

Carannante, S., Argnani, A., Augliera, P., Cattaneo, M., D’Alema, E., Franceschina, G., Lovati, S., Massa, M., Monachesi, G., Moretti, M., 2014. Risultati da Progetto Sismologico S1 (INGVDPC 2013) Base-knowledge improvement for assessing the seismogenic potential of Italy Section n: D18/b2 Relocated seismicity in the Po Plain. Workshop Terremoto Emilia 2012, Roma 26 Maggio 201. 
995

996

997

998

999

1000

1001

1002

1003

1004

1005

1006

1007

1008

1009

1010

1011

1012

1013

1014

1015

1016

1017

1018

1019

1020

1021

1022

1023

1024

1025

1026

1027

1028

Carminati, E., Doglioni,C., 2012. Alps vs. Apennines: the paradigm of a tectonically asymmetric Earth. Earth-Science Reviews, 112, 67-96.

Carminati, E., Cavazza, D., Scrocca, D., Fantoni, R., Scotti, P., Doglioni, C., 2010. Thermal and tectonic evolution of the southern Alps (northern Italy) rifting: Coupled organic matter maturity analysis and thermokinematic modelling. AAPG Bulletin, v. 94, no. 3 (March 2010), pp. 369-397.

Carr, A.D., 1999. A vitrinite reflectance kinetic model incorporating overpressure retardation. Marine and Petroleum Geology, 16, 355-377.

Carulli, G.B, Salvador, G.L., Ponton, M., Podda, F., 1997. La dolomia di forni: evoluzione di un bacino euxinico tardo triassico nelle prealpi carniche. Boll. Soc. Geol. It., 116, 95-107.

Casati, P., Assereto, R., Comizzoli, G., Passeri, L.D., Boni, A., Cassinis, G., Cerro, A., Rosetti, R., Accordi, B., Dieni, I., Malaroda, R., Bianchi, A., Cevales, G., Dal Piaz, Gb., Morgante, S., 1970. Carta Geologica D’Italia scale 1:100,000, Map “34- Breno”.

Casero, P., 2004. Structural setting of petroleum exploration plays in Italy. In Crescenti, V., D’Offizi, S., Merlino, S., Sacchi, L. (Eds), Geology of Italy. Special Volume of the Italian Geological Society for the IGC $32^{\text {nd }}$, Florence, 189-199.

Cassano, E., Anelli, L., Fichera, R., Cappelli, V., 1986. Pianura Padana, interpretazione integrata di dati Geofisici e Geologici. - $73^{\circ}$ congresso Soc. Geol. It., Roma.

Castellarin, A., Vai, G.B., 1982. Introduzione alla geologia strutturale del Sudalpino. In: Castellarin, A., Vai,G.B., - Guida alla gelogia del Sudalpino centro orientale. Guide Geol. Reg., Soc.Geol.It., 1-22.

Castellarin A., Eva C., Giglia G., Vai G.B., Rabbi E., Pini G.A. \& Crestana G., 1985. Analisi strutturale del Fronte Appenninico Padano. Giornale di Geologia, 47, pp.47-75.

Castellarin, A., 2001. Alps-Apennines and Po Plain-Frontal Apennines relationships. In: VAI G. B. \& MARTINI I. P. (Eds.), Anatomy of an Orogen. The Apennines and adjacent Mediterranean Basins, Kluver, London, 177- 196.

Castiglioni,B., Leonardi, P., Merla, G., Trevisan., Zenari, S., 1940. Carta geologica delle Tre Venezie, scale 1:100,000, Map “12- Pieve di Cadore”.

Castiglioni, B., Boyer, G., Leonardi, P., Venzio, S., Dal Piaz, G., Vialli, V., Zenari, S., 1941. Carta geologica delle Tre Venezie, scale 1:100,000, Map “23- Belluno”.

Cati, A., Sartorio, D., Venturini, S., 1987. Carbonate platforms in the subsurface of the northern Adriatic area. Mem.Soc. Geol.It., v.40. pp. 295-308.

Ciarapica, G., Cirilli, S., D’Argenio, B., Marsella, E., Passeri, L., Zaninetti, L., 1986. Late Triassic open and euxinic basins in Italy. Rend.Soc.Geol.It., 9, pp.157-166. 
Chiaramonte, M.,A., Novelli, L., 1986. Organic matter maturation in Northern Italy: some determining agents. Org. Geochem., 10, 281-290.

Dal Piaz, G., Venzo,S., Fabiani, R., Trevisan, L., Pia, J., 1946. Carta geologica delle Tre Venezie, scale 1:100,000, Map “37-Bassano del Grappa”.

Defant, A., 1961. Physical Oceanography, Vol. 1, Pergamon Press, 728 pp.

Della Vedova, B., Bellani, S., Pellis, G., Squarci, P., 2001. Deep temperatures and surface heat flow distribution. In: VAI G.B. \& MARTINI I.P. (Eds.): "Anatomy of an orogen: the Apenninesand adjacent Mediterranean basins". Kluwer Academic Publishers: 65-76, Dordrecht, The Netherlands.

Desio, A., Venzo, S., 1954. Carta Geologica D’Italia, scale 1:100,000, Map “33- Bergamo”.

Dewey, J.F.; Pitman, C., Ryan, B. F., Bonnin, J. 1973. Plate tectonics and the evolution of the Alpine systems. Geological Society of America Bulletin, 84, 3,137-80.

De Zanche, V., Gianolla, P., Roghi, G., 2000. Carnian stratigraphy in the Raibl/Cave del Predil area (Julian Alps, Italy). Eclogae. Geol. Helv., 93, 331-347.

Doglioni, C., Bosellini, A., 1987. Eo-Alpine and meso-Alpine tectonics in the Southern Alps. Geol. Rundsch. 76 (3), 735-754.

Di Giulio, A., Mancin, N., Martelli, L., Sani, F., 2013. Foredeep palaeobathymetryand subsidence trends during advancing then retreating subduction: the Northern Apennine case (Oligocene-Miocene, Italy). Basin Research (2013) 25, 260-284, doi: 10.1111/bre.12002.

Errico, G., Groppi, G., Savelli, S., Vaghi G.C., 1980. Malossa Field: a deep discovery in the Po Valley, Italy - AAPG Memoir 30, 525-538.

Fantoni, R., Bello, M., Ronchi, P., Scotti, P., 2002. Po Valley oil play - From the VillafortunaTrecate field to South Alpine and Northern Apennine exploration. EAGE 64th Conference \& Exhibition - Florence, Italy, 27 - 30 May 2002.

Fantoni, R., Scotti, P., 2003. Thermal record of the Mesozoic extensional tectonics in the Southern Alps - Atti Ticinensi di Scienze della Terra 9, 96-101.

Fantoni, R., Decarus, A., Fantoni E., 2003. Mesozoic extension at the Western margin of the Southern Alps (Northern Piedmont, Italy) - Atti Ticinensi di Scienze della Terra 44, 97-110.

Fantoni, R., Bersezio, R., Forcella, F., 2004. Alpine structure and deformation chronology at the Southern Alps-Po Plain border in Lombardy. Boll.Soc.Geol.It., 123 (2004), 463-476.

Fantoni R., Franciosi R., 2010. Tectono-sedimentary setting of the Po Plain and Adriatic foreland - Rend.Fis.Acc.Lincei, 21, (Suppl 1):S197-S209, DOI 10.1007/s12210-010-0102-4. 
Franciosi R. \& Vignolo A., 2002. Northern Adriatic foreland- a promising setting for the south Alpine Mid-Triassic Petroleum system. EAGE $64^{\text {th }}$ Conference \& Exhibitions, Florence, Italy, 27-30May 2002.

Galli, M.T., Jadoul, F., Bernasconi, S.M., Cirilli, S., Weissert, H., 2007. Stratigraphy and palaeoenvironmental analysis of the Triassic-Jurassic transition in the western Southern Alps (Northern Italy). Palaeogeography, Palaeoclimatology, Palaeoecology, 44, 52-70

Gatto, G.O., Gatto, P., Baggio, P., De Vecchi, Gp., Mezzacasa, G., Piccirillo, E., Zirpoli, G., Friz., Gatto, G., Corsi, M., Sassi, F.P., Monese,A., Gregnanin, A., Zilian, T., Largaiolli, T., 1969. Carta Geologica D’Italia, scale 1:100,000, Map “1 \& 4A- Passo del Brennero and Bressanone".

Gatto, P., Rui, A., Dal Pra,A., De Zanche,V., Gatto, G., Gatto, G.O., Corsi, M., Nardin, M., Sacerdoti, M., Largaiolli, T., Ghezzo, C., D’Amico, C., 1968. Carta Geologica D'Italia, scale 1:100,000, Map “21-Trento”.

Ghielmi, M., Minervini, M., Nini, C., Rogledi, S., Rossi, M., 2012. Late Miocene-Middle Pleistocene sequences in the Po Plain and the Northern Adriatic Sea (Italy): The stratigraphic record of modification phases affecting a complex foreland basin. Marine and Petroleum Geology, http://dx.doi.org/ 10.1016/j.marpetgeo.2012.11.007.

Gianolla, P., De Zanche, V., Mietto, P., 2012. Triassic sequence stratigraphy in the Southern Alps (Northern Italy): definition of sequences and basin evolution. SEPM Special Publication No. 60, ISBN 1-56576-043-3.

Gnaccolini, M., Jadoul, F., 1990. Carbonate platform, lagoon and delta "high-frequency" cycles from the Carnian of Lombardy (Southern Alps, Italy). Sedimentary Geology, 67, 143-159.

Gortani, M., Desio, A., 1925. Carta geologica delle Tre Venezie, scale 1:100,000, Map “14Pontebba".

Greber, E., W. Leu, D. Bernoulli, M. Schumacher, and R. Wyss, 1997. Hydrocarbon provinces in the Swiss southern Alps-A gas geochemistry and basin modelling study. Marine and Petroleum Geology, v. 14, p. 3-25, doi:10.1016/S0264-8172(96)00037-2.

Gretner, P.E., 1981. Geothermics: using temperature in hydrocarbon exploration. AAPG, Short Course Notes, 17.

Grobe, A., Littke, R., Sachse, V., Leythaeuser, D., 2015. Burial history and thermal maturity of Mesozoic rocks of the Dolomites, Northern Italy. Swiss Geological Society, doi 10.1007/s00015-015-0191-2.

Gusterhuber, J., Hinsch, R., Sachsenhofer, R.F., 2014. Evaluation of hydrocarbon generation and migration in the Molasse fold and thrust belt (Central Eastern Alps, Austria) using structural and thermal basin models. AAPG Bulletin, v. 98, no. 2, pp. 253-277. 
Handy, R., Ustaszewski, K., Kissling, E., 2014. Reconstructing the Alps-Carpathians-Dinarides as a key to understanding switches in subduction polarity, slab gaps and surface motion. International Journal of Earth Science (Geol Rundsch) - DOI 10.1007/s00531-014-1060-3.

Jadoul, F. 1986, Stratigrafia e Paleogeografia del Norico nelle Prealpi bergamasche occidentali. Riv.It.Paleoont.Strat, v.91,n.4 pp.479-512.

Jadoul, F., Berra F. 7 Frisia, S., 1992. Stratigrafic and palaeogeographic evolution of a carbonate platform in an extensional tectonic regime:the example of the Dolomia Principale in Lombardy (Italy). Riv.It.Paleont.Strat., v.98,n.1,pp.29-44.

Jadoul, F., Nicora A., Ortenzi A., Pohar C., 2002. Ladinian stratigraphy and palaeogeography of the Southern Val Canale (Pontebbano-Tarvisiano, Julian Alps, Italy). Mem Soc.geol It., v57, pp29-43.

Jarvie, D.M.., Claxton, B.L., Henk, F., Breyer, J.T., 2001. Oil and Shale Gas from the Barnett Shale, Ft. Worth Basin, Texas, AAPG National Convention, June 3-6, 2001, Denver, CO, AAPG Bull. Vol. 85, No. 13 (Supplement), p.A100.

Katz, B.J., Dittmar, E.I., Ehret, G.E., 2000. A geochemical review of carbonate source rocks in Italy. Journal of Petroleum Geology, v.23 (4), pp.399-424.

Keim, L., Spötl, C., and Brandner, R., 2006. The aftermath of the Carnian carbonate platform demise: a basinal perspective (Dolomites, Southern Alps): Sedimentology, v. 53 p. 361-386, doi: 10.1111/j.1365-3091.2006.00768.x.

Lindquist, S.J., 1999. Petroleum systems of the Po Basin province of northern Italy and the northern Adriatic Sea; U.S. Geological Survey Open-File Report 99-50-M, 19 p., 15 figs., 3 tables.

Lipparini, T., Perrella, G., Medioli, F., Venzo,S., Barbier, F., Malaroda, R., Sturani, C., Carraro, F., Zanella, E., Corsi, M., Gatto, G., Piccoli, G., 1969. Carta Geologica D'Italia, scale 1:100,000, Map “48-Peschiera del Garda".

Mackenzie, A. S., \& Quigley, T. M. (1988). Principles of geochemical prospect appraisal. AAPG Bulletin, 72(4), 399-415.

Mann, D. M., Mackenzie, A. S., 1990. Prediction of pore fluid pressures in sedimentary basins: Marine and Petroleum Geology, 7, no. 1, 55-65, http://dx.doi.org/10.1016/02648172(90)90056-M.

Masetti, D., Fantoni, R., Romano, R., Sartorio, D., Trevisani, E., 2012. Tectonostratigraphic evolution of the Jurassic extensional basins of the eastern southern Alps and Adriatic foreland based on an integrated study of surface and subsurface data. AAPG Bulletin, v. 96, no. 11, pp. 2065-2089.

Mattavelli, L., Novelli, L., 1987. Origin of the Po basin hydrocarbons - Mémoires de la Société Géologique de France, nouvelle série. 151; 97-106. 
Mattavelli, L., Margarucci, V., 1992. Malossa Field - Italy, Po Basin, in Foster, N.H., and Beaumont, E.A., Treatise of Petroleum Geology, Atlas of Oil and Gas Fields, Structural Traps VII: Tulsa, OK, American Association of Petroleum Geologists, p. 119-137.

Mattavelli, L., Pieri, M., Groppi, G., 1993. Petroleum exploration in Italy: a review. Marine and Petroleum Geology, 10, 410-425.

Mattirolo, E. Novarese, V., Franchi, S., Stella, A., 1927. Carta Geologica D'Italia, scale 1:100 000, Map “30- Varallo”.

Michetti, A.M., Giardina, F., Livio, F., Mueller, K., Serva, L., Sileo, G., Vittori, E., Devoti, R., Riguzzi, F., Carcano, C., Rogledi, S., Bonadeo, L., Brunamonte, F., Fioraso, G., 2013. Active compressional tectonics, Quaternary capable faults, and the seismic landscape of the Po Plain (northern Italy). Ann. Geophys. 55 (5), 969-1001, doi:10.4401/ag-5462.

Middleton M. (1993) A transient method of measuring the thermal properties of rocks. Geophysics, 58, 357-365.

Nardin, M., Rossi, D., Sommavilla, E., Largaiolli, T., Mozzi, G., Gregnanin, A., Zulian, T., Zirpoli, G., Corsi, M., Gatto, G.O., Gatto, P., Graga, Gp., Rui, a., 1970. Carta Geologica D’Italia, scale 1:100,000, Map “22- Feltre”.

Nardon, S., Marzorati, D., Bernasconi, A., Cornini, S., Gonfalini, M., Mosconi, S., Romano, A., Terdich, P., 1991. Fractured carbonate reservoir characterization and modelling a multidisciplinary case study from the Cavone oil field, Italy: First Break, 9, 12, 553-565.

Neumaier, M., Littke, R., Hantschel, T., Maerten, L., Joonnekindt, T., Kukla, P., 2014. Integrated charge and seal assessment in the Monagas fold and thrust belt of Venezuela. AAPG Bulletin, v. 98, no. 7, pp. 1325-1350.

Novelli, L., Chiaramonte, M. A., Mattavelli, L., Pizzi, G., Sartori, L., Scotti, P., 1987. Oil habitat in the northwestern Po Basin, in B. Doligez, ed., Migration of hydrocarbons in sedimentary basins: Paris, Editions Technip, p. 27-57.

Pasquale,V., Gola, G., Chiozzi,P., Verdoya, M., 2011. Thermophysical properties of the Po Basin rocks. Geophys. J. Int., 186, 69-81. doi: 10.1111/j.1365-246X.2011.05040.x

Pasquale,V., Chiozzi, P., Verdoya, M., Gola, G., 2012. Heat flow in theWestern Po Basin and the surrounding orogenic belts. Geophys. J. Int., 190, 8-22. doi: 10.1111/j.1365246X.2012.05486.x.

Passeri, L.D., Comizzoli, G., Assereto, R., 1967. Carta Geologica D'Italia, scale 1:100,000, Map "14 A- Tarvisio".

Pepper, A. S., Corvi, P.J., 1995a. Simple kinetic models of petroleum formation. Part I: Oil and Gas generation from kerogen. Marine and Petroleum Geology, v. 12, no. 3, p. 291-319.

Pepper, A. S., Corvi, P.J., 1995b. Simple kinetic models of petroleum formation. Part III: Modelling an open system. Marine and Petroleum Geology, v. 12, no. 4, p. 417-452. 
Pepper, A.S., Dodd, T.A., 1995. Simple kinetic models of petroleum formation. Part II : oil-gas cracking. Marine and Petroleum Geology, v. 12, no. 3, p. 321-340.

Pieri, M., Groppi,G., 1981. Subsurface geological structure of the Po Plain, Italy. Prog.Fin. Geodinamica CNR, pubbl.414, Roma, 1-113.

Pieri M., 1984. Storia delle ricerche nel sottosuolo padano fino alle ricostruzioni attuali - Cento anni di geologia Italiana, Volume Giubilare, $1^{\circ}$ Centenario della Soc.Geol.Ital. 1881-1981, Roma, 155-177.

Pieri, M., 2001, Italian petroleum geology- In: G.B.Vai and I.P. Martini (eds), Anatomy of an Orogen: the Apennines and Adjacent Mediterranean Basins, pp.533-550.

Pietro, B., Raffaele, D., \& Diego, G. (1979, January 1). Deep Drilling In Po Valley: Planning Criteria And Field Results. Society of Petroleum Engineers. doi:10.2118/7847-MS

Pfiffner, A., 2014. Geology of the Alps. Wiley Blackwell, pp. 368.

Ponton, M., 2010. Architettura delle Alpi Friulane. Museo Friulano di Storia Naturale, Publ. $\mathrm{N}^{\circ}$ 52, Udine, ISBN 9788888192529.

Ravaglia, A., Seno, S., Toscani, G., Fantoni, R., 2006. Mesozoic extension controlling the Southern Alps thrust front geometry under the Po Plain, Italy: Insights from sandbox models. Journal of Structural Geology 28, 2084-2096.

Rigo, F., 1991, Italy to open 'exclusive' Po basin area in 1992. Oil and Gas Journal, v. 89, no. 21 102-106.

Riva, A., Salvatori, T., Cavaliere, R., Ricchiuto, T., Novelli, L., 1986. Origin of oils in Po Valley, Northern Italy - Organic Geochemistry, 10, 391-400.

Rossi, M., Minervini, M., Ghielmi, M. \& Rogledi, S., 2015. Messinian and Pliocene erosional surfaces in the Po Plain-Adriatic Basin: Insights from allostratigraphy and sequence stratigraphy in assessing play concepts related to accommodation and gateway turnarounds in tectonically active margins. Marine and Petroleum Geology, 66, 192-216.

Sassi, F.P., Zirpoli, G., Nardin, M., Sacerdoti, M., Bosellini, A., Largaiolli, T., Leonardi, P., Sommavilla, E., MOzzi, G., Rossi, D., Proto Decima, F., Dal Monte, M., Paganelli, L., Simboli, G., Gatto, P., 1970. Carta Geologica D'Italia, scale 1:100,000, Map “11- M. Marmolada”.

Scotti, P., 2005. Thermal constraints suggested by the study of the organic matter and thermal modelling strategies: A case history from the southern Alps: Atti Ticinensi di Scienze della Terra, Serie Speciale, v. 10, p. 21-35.

Scotti, P., Fantoni, R., 2008. Thermal modelling of the extensional Mesozoic succession of the Southern Alps and implications for oil exploration in the Po Plain foredeep. $70^{\text {th }}$ EAGE Congerence \& Exhibition - Rome, Italy, 0-12 June, 2008.

Sekiguchi, K., 1984. A method for determining terrestrial heat flow in oil 
basinal areas. Tectonophysics, 103, 67etho

Shonborn,G., 1992. Alpine tectonics and kinematics of the central Southern Alps. Memorie di Scienze Geologiche; vol XLIV, pp. 229-393.

Shonborn,G., 1999. Balancing cross sections with kinematic constraints: the Dolomites (northern Italy). Tectonics, 18, 3, pp. 527-545.

Stefani, M., and Burchell, M., 1990. Upper Triassic (Rhaetic) argillaceous sequences in northern Italy: depositional dynamics and source potential, in Hue, A.Y., (Eds.), Deposition of Organic Facies, AAPG Studies in Geology \#30: Tulsa, OK, American Association of Petroleum Geologists, p. 93-106.

Sweeney, J.J., and Burnham, A.K., 1990. Evaluation of a simple model of vitrinite reflectance based on chemical kinetics: American Association of Petroleum Geologists Bulletin, v. 74, p. $1559-1570$.

Tissot, B. P., and D. H. Welte, 1984, Petroleum formation and occurrence, 2nd ed: New-York, Springer Verlag, $699 \mathrm{p}$.

Turrini, C., Lacombe, O., Roure, F., 2014. Present-day 3D structural model of the Po Valley basin, Northern Italy. Marine and Petroleum Geology 56, 266-289.

Turrini, C., Angeloni, P., Lacombe, O., Ponton, M., Roure, F., 2015. Three-dimensional seismo-tectonics in the Po Valley basin, northern Italy. Tectonophysics, 661, 156-179. http://dx.doi.org/10.1016/j.tecto.2015.08.033.

Turrini, C., Toscani, G., Lacombe, O., Roure, F., 2016. Influence of structural inheritance on foreland-foredeep system evolution: an example from the Po Valley region (northern Italy). Marine and Petroleum Geology, 77, 376-398.

Vaghi, G.C., Torricelli, L., Pulga, M., Giacca, D., Chierici, G.L., and Bilgeri, D., 1980, Production in the very deep Malossa field, Italy: Proceedings 10th World Petroleum Congress, Bucharest, v. 3, p. 371-388

Vannoli, P., Burrato, P., Valensise, G., 2014. The seismotectonics of the Po Plain (northern Italy): tectonic diversity in a blind faulting domain. Pure Appl. Geophys., doi:10.1007/s00024014-0873-0.

Waples, D.W., Waples, J.S., 2004 A review and evaluation of specific heat capacities of rocks, minerals, and subsurface fluids. Part 2, fluids and porous rocks. Nat Resour Res 13:123-130.

Winterer, E. L., Bosellini, A., 1981. Subsidence and sedimentation on Jurassic passive continental margin, southern Alps, Italy: AAPG Bulletin, v. 65, p. 394-421.

Wygrala, B.P., 1988. Integrated computer-aided basin modelling applied to analysis of hydrocarbon generation history in a Northern Italian oil field. Advances in Organic Geochemistry, 13, 1-3, pp. 187-197. 
Zou Yan-Rong, Peng Ping'an, 2001. Overpressure retardation of organic-matter maturation : a kinetic model and its application. Marine and Petroleum Geology, 18, 707-713.

Zappaterra, E., 1994. Source-Rock distribution Model of the Periadriatic Region. AAPG Bullettin, v.78, n.3, pp.333-35.

Zattin, M., Cuman, A., Fantoni, R., Martin, S., Scotti, P., Stefani, C., 2006. From middle Jurassic heating to Neogene cooling: the thermochronological evolution of the Southern Alps. Tectonophysics, 414, 191-202.

Figure Captions \& Tables

Fig.1 - Regional setting, tectono-stratigraphic framework and petroleum system of the Po Valley basin: a) location map of the study area , major oil fields at Mesozoic level and major cities $(\mathrm{Mi}=$ Milano, $\mathrm{To}=$ Torino, $\mathrm{Ge}=$ Genova, $\mathrm{Ve}=$ Venezia $) ; \mathrm{a}=$ Milan tectonic arc, $\mathrm{b}=$ Monferrato arc, $\mathrm{c}=$ Emilia arc, $\mathrm{d}=$ Ferrara arc $; 1=$ Insubric line, $2=$ Giudicarie line, 3=Schio-Vicenza line, 4=Sestri-Voltaggio line; b) Structural cross section (red dashed line in "a") through study area showing present day geometries of main structural elements and hydrocarbon distribution; c) major stratigraphic units, stratigraphy and hydrocarbon distribution: yellow circle is mainly biogenic gas; red circle is thermogenic oil in Tertiary successions; green circle is thermogenic oil \& condensate in Triassic carbonates

Fig.2 - Grid showing depth to Top Mesozoic Carbonates (referenced to mean sea level, contouring every $500 \mathrm{~m}$; bold black lines are major faults at the top of the Mesozoic carbonates); Purple lines " $a$ " and " $b$ " show the location of the cross-sections in Figure 3. GFz = Giudicarie Fault zone trend line (thick stippled line) separating the eastern domain from the western domain; thin stippled white line marks the area covered by the basin modelling study described in this paper; bold red line represents overpressure cell suggested by Chiaramonte \& Novelli (1986); Major cities: $\mathrm{Mi}=$ Milano, To $=$ Torino, $\mathrm{Ge}=$ Genova, $\mathrm{Ve}=$ Venezia.

Fig. 3 - a, b = regional cross-sections through the 3D Po Valley structural model and main tectonic units; $\mathrm{c}=$ cross-section location map at top Mesozoic Carbonate level (see Fig.2 for larger view). 
Fig. 4 - The Villafortuna oil-field structure (see location in Figs.1 and 2): a) top Mesozoic depth grid; RF = Romentino thrust front; b) 3D structural model of the field structure, c) and d) crosssections through the 3D model. $\mathrm{R} / \mathrm{Sr}=$ Reservoir and Source; $\mathrm{Sl}=$ Seal; $\mathrm{RF}=$ Romentino thrust front. Note: the Romentino unit geometry within the Oligo-Miocene section in Fig.4c \& 4d is sketched from Pieri \& Groppi, 1981, Cassano et al., 1986, Bello \&Fantoni, 2002.

Fig.5 - The Gaggiano oil-field and the Lacchiarella structure (see location in Figs.1 and 2): a) top Mesozoic depth grid, b) 3D structural model of the field and the surrounding structures, c), d) and e) cross-sections through the 3D model. $\mathrm{R} / \mathrm{Sr}=$ Reservoir and Source; $\mathrm{Sl}=$ Seal. Note: the extensional terraces in the footwall of the Lacchiarella inverted fault (dotted-lines) are sketched based on Cassano et al., 1986, Bongiorni, 1987, Fantoni et al.2004.

Fig.6 - The Malossa oil-field region (see location in Figs.1 and 2): a) top Mesozoic depth grid, b) 3D structural model of the field and the surrounding structures, c), d) and e) cross-sections through the 3D model. $\mathrm{R} / \mathrm{Sr}=$ Reservoir and Source; $\mathrm{Sl}=$ Seal. Belvedere well is projected onto section.

Fig. 7 - The Cavone oil-field structure (see location in Figs.1 and 2): a) top Mesozoic depth grid, b) 3D structural model of the field and the surrounding structures, c), d) and e) crosssections through the $3 \mathrm{D}$ model. $\mathrm{R} / \mathrm{Sr}=$ Reservoir and Source; $\mathrm{S} 1=$ Seal. Note: the stippled segments inside the Cavone thrust-related stack are cross-faults sketched from Nardon et al., 1991.

Fig. 8 - Lithostratigraphy and sediment distribution: a) Triassic-Liassic chrono-stratigraphy of the Po Valley region highlighting the main source rock intervals; b) Gross depositional environment (GDE) map of the Anisian to late Carnian sediments; c) Gross depositional environment map of the late Carnian-early Liassic sediments. Data source : Gortani \& Desio, 1925; Mattirolo et al., 1927; Castiglioni et al., 1940 and 1941; Dal Piaz et al., 1946; Desio \& Venzo, 1954; Andreatta et al., 1957; Passeri et al., 1967; Braga et al., 1968; Gatto et al., 1968 and 1969; Lipparini et al., 1969; Casati et al., 1970; Nardin et al., 1970; Sassi et al., 1970 ; Cantelli et al., 1971; Castellarin \& Vai, 1982; Jadoul, 1986; Cati et al., 1987; Ciarapica et al., 1986; Doglioni \& Bosellini, 1987; Jadoul et al., 1992; Shonborn, 1992, 1999; Bertotti et al., 1993; Zappaterra, 1994; Greber et al., 1997; De Zanche et al., 2000; Franciosi \& Vignolo, 2002; Jadoul et al., 2002; Fantoni \& Scotti, 2003; Fantoni et al., 2003, 2004; Berra et al., 2009; 
Bertello et al., 2010; Fantoni \& Franciosi, 2010; Ponton, 2010; Gianolla et al.,2012, Masetti et al., 2012; Handy et al., 2014; Pfiffner, 2014.

Fig.9 - Synthetic well logs for the Belvedere 1 well (depth is in metres): (a) Chrono- \& Lithostratigraphy; (b) Formation pressure model showing the significant increase in overpressure below $2000 \mathrm{~m}$ through the Tertiary foredeep clastics and basinal carbonates into the highly overpressured deep carbonate aquifer consisting of Liassic and Triassic platform limestones and dolomites; (c) temperature model showing good correspondence between corrected well temperature measurements and the prediction from the basin model. The average temperaturedepth trend for the Western Po Valley from Pasquale et al (2012) together with the observed range is also shown; and (d) thermal maturity model showing match of various models to the dataset from Chiaramonte \& Novelli (1986).

Fig. 10 - Heat flow histories of the Po Valley and surrounding regions (see text for explanations).

Fig. 11 - 1D Transformation Ratio (TR) maturity histories for four wells from the Po Valley based on initial source rock parameters outlined in Table 1 (TR scale is 0-100): (a) Cerano-1 from the western Po Valley; (b) Belvedere-1 from the central Po Valley; (c) a pseudo-well from the east-central Po Valley; and (d) Ballan-1 from the eastern Po Valley (see Fig. 2 for well locations). Vitrinite reflectance maturities are shown as blue lines (note that for wells in (a) and (b), two histories are shown for the last 10Ma: one based on the geological heat flow and one based on reduced heat flow from end Miocene times to replicate the effect of overpressure; wells in (c) and (d) lie outside of the overpressure cell; see text for explanations).

Fig. 12 - Transformation ratio (TR) maturity maps (TR scale is $0-1$ ) for the middle Triassic (ac) and the Late Triassic (d-f) source intervals, for end Jurassic (a, d), end-Cretaceous (b, e) and end Miocene (c, f) times. As the onset of overpressure within the carbonate sequences is interpreted to occur at end Miocene, there is no difference between the maturity levels associated with the geological heat flow and the overpressure models for this time interval.

Fig. 13 - Present day transformation ratio (TR) maturity maps (TR scale is 0-1) for the middle Triassic ( $a$ and b) and the Late Triassic (c and d) source intervals; (a) and (c) show the results 
of geological heat flow model with (b) and (d) showing the results for the overpressure model, based on the application of reduced Plio-Pleistocene heat flow as described in the text.

Fig.14 - Charge timing versus trap formation in the Western Po Valley based on preferred Overpressure Model (see text for discussion). Vertical orange arrows indicate the presumed critical moment for each of the traps, i.e., the time at which the trap formed or the seal became able to retain a hydrocarbon column.

Fig. 15 - Model evaluation: (a) cross plot of observed in place volumes for main traps versus available charge from kitchen area since the critical moment predicted by the models; (b) cross plot of observed volumes in-place for main traps versus predicted trapped volumes from the models; (c) cross plot of observed-GOR versus predicted-GOR from the models. Red data points and regression lines are for the geological heat flow model, blue data points and regression lines are for the overpressure model. For plot (b) regression lines have been fitted to the dataset excluding the Gaggiano outlier. In all plots the black line corresponds to a perfect match between observation and model.

Table 1 - Po Valley 3D basin modelling workflow and associated working phases.

Table 2 - Table of source rock parameters used in thermal modelling of the Po Valley. Parameters are from published data on the Po Valley Triassic source intervals as reported for the Villafortuna-Trecate and Malossa fields, as well as outcrop analogues. Colours correspond to Gross depositional environments in Fig.8. Kerogen Types A ("Aquatic, marine, siliceous or carbonate/ evaporitic") \& F ("Terrigenous, non-marine, wax-poor") are as defined by Pepper \& Corvi (1995 a, b). These are analogous to Kerogen Type IIS and Kerogen Type III/Type IV, respectively, as by Tissot \& Welte (1984).

Table 3 - Table of rock properties used in basin modelling of the Po Valley. Where available, local rock properties are used (Berra \& Carminati, 2010; Pasquale et al, 2011; Pasquale et al, 2012). Other values are from global averages (Gretner, 1981; Waples \& Waples, 2004; Middleton, 1993). 


\section{Phase1 - 1D model building}

Reference well and pseudo-well chrono-litho-stratigraphy, back-stripping parameters, thermal parameters, source rock parameters, temperature and maturity data loaded into Genesis (http://www.zetaware.com/);

- Definition of geological heat flow and overpressure models, primarily based on the available literature;

- Collation of information about palaeo-water depth and palaeo-sediment/water interface temperature.

\section{Phase 2-1D model calibration and outputs}

- Calibration of rock property and present-day heat flow model against temperature data;

- Calibration of back-stripping and heat flow models by forward modelling of thermal maturity and comparison against available maturity data;

- 1D modelling of hydrocarbon generation from key source intervals.

\section{Phase 3-3D model building \& simulation}

- 3D stratigraphic grids exported from the Kingdom package into the Trinity software, with additional grids generated by interpolating between imported grids as necessary, particularly to define source rock intervals;

- Further definition of source intervals within the model, including lateral distribution from gross depositional environment (GDE) maps, thickness and kerogen type as described in the literature;

- Definition of 3D palaeo-temperature model by calibration against $1 \mathrm{D}$ models for key wells and pseudo-wells;

a 3D hydrocarbon maturation/generation/migration history modelling across the Po Valley and analysis of kitchen areas associated with key traps. 
Table 2 - Source rock parameters

\begin{tabular}{|c|c|c|c|c|c|c|c|c|c|c|c|}
\hline \multirow[b]{2}{*}{ Source Age interval } & \multirow[b]{2}{*}{ Domain } & \multirow[b]{2}{*}{ Focmation(s) } & \multirow[b]{2}{*}{$\begin{array}{l}\text { Net } \\
\text { Thickness } \\
\text { (m) }\end{array}$} & \multirow[b]{2}{*}{$\operatorname{TOC}(\%)$} & \multicolumn{2}{|c|}{ Kerogen Trpe } & \multirow[b]{2}{*}{ Weight (\%) } & \multirow[b]{2}{*}{$\begin{array}{l}\text { Hydrogen } \\
\text { Index }\end{array}$} & \multicolumn{3}{|c|}{ Petroleum Potential } \\
\hline & & & & & $\begin{array}{c}\text { Tissot \&. } \\
\text { Weite, } \\
1984\end{array}$ & $\mid \begin{array}{c}\text { Pepper \& } \\
\text { Corvi, } \\
1995 a\end{array}$ & & & $\begin{array}{l}\text { mg HClg } \\
\text { Rock }\end{array}$ & $\begin{array}{c}\mathrm{mmbb} / / \\
\mathrm{K} \mathrm{m}^{2}\end{array}$ & $\mathrm{bct} / \mathrm{Km}^{2}$ \\
\hline \multirow{4}{*}{ Upper Triassic } & \multirow{2}{*}{ tong-lived anoxic basin } & \multirow{2}{*}{$\begin{array}{l}\text { Argile dif Fiva di Solto; } \\
\text { Formi }\end{array}$} & \multirow{2}{*}{50} & \multirow{2}{*}{4} & ins & A & 90 & 550 & 19.8 & 179 & \\
\hline & & & & & III & $F$ & 10 & 160 & 0.64 & & 3.9. \\
\hline & \multirow{2}{*}{$\begin{array}{c}\text { Intra-platform/ramp } \\
\text { tagoon }\end{array}$} & \multirow{2}{*}{$\begin{array}{l}\text { Dolornia Principale, } \\
\text { Monticello, Calcare di Zu, } \\
\text { Scisti Bituminosi. }\end{array}$} & \multirow[b]{2}{*}{12.5} & \multirow[b]{2}{*}{4} & 75s & A & 90 & 550 & 19.8 & 45 & \\
\hline & & & & & 口i & F & 10 & 160 & 0.64 & & 1 \\
\hline \multirow{6}{*}{ Middle Triassic } & \multirow{2}{*}{ Long-thed anoxic basit } & \multirow{2}{*}{ Meride, 8esano } & \multirow{2}{*}{50} & \multirow{2}{*}{4} & its & A. & 90 & 550 & 19.8 & 179 & \\
\hline & & & & & III & $\mathrm{F}$ & 10. & 160 & 0.64 & & 3.9 \\
\hline & \multirow{2}{*}{ Episodically anoxic basin } & \multirow{2}{*}{$\begin{array}{l}\text { Meride, tiwinallongo, } \\
\text { Moena, Rio det Laso }\end{array}$} & \multirow{2}{*}{25} & \multirow{2}{*}{4} & is & A & 90 & 550 & 19.8 & 9 & \\
\hline & & & & & III & $\mathrm{F}$ & 10 & 160 & 0.64 & & 2 \\
\hline & \multirow{2}{*}{$\begin{array}{c}\text { Intra-platform/ramp } \\
\text { lagoon }\end{array}$} & \multirow{2}{*}{ Gorno: } & \multirow{2}{*}{12.5} & \multirow{2}{*}{4} & DS & A & 10 & 550 & 2.2 & 4 & \\
\hline & & & & & III & $\mathrm{F}$ & 90 & 160 & 5.76 & & 70.9 \\
\hline
\end{tabular}


Table 3-Rock properties

\begin{tabular}{|c|c|c|c|c|c|c|c|c|c|c|}
\hline \multicolumn{11}{|c|}{ Fooks Propentifs } \\
\hline Food type & Shair & Sanditone & Chalk: & $\begin{array}{c}\text { Cherr } \\
\text { Radiolerites }\end{array}$ & Umestone & Dolomite & Antydrite & St & Mart & Congloenerate \\
\hline Surface porosity & 0.29 & 0.28 & 020 & 0.70 & 0,2 & 0.30 & 0.63 & 0.29 & 0.50 & 0.40 \\
\hline Compuction Coefficient & 0.38 & 022 & 0.72 & 0.71 & 052 & 0.22 & 052 & 0.38 & 0.54 & 0.23 \\
\hline Porosity at $3000 \mathrm{~m}$ (using Ashy eq. $\varphi(z)=p_{0} e^{-1}$ ) & 0.09 & a.15 & 0.08 & 0.08 & a.1 & 0.16 & 0.13 & 0.00 & 0.10 & 0.20 \\
\hline Bulk density (kes/m') & 2720 & 2650 & 2710 & 2650 & 2710 & 2710 & 2270 & 2650 & 2715 & 2650 \\
\hline Theratial conductivity $(w / m / x)$ & 1.62 & 385 & 3.14 & 7.11 & 3.14 & 4.98 & 4.76 & 3.35 & 2.25 & 4.18 \\
\hline Ternoerature Dependency of themal conductivivil/Ci & 0.0004 & 0.0019 & 0,0015 & 0.0030 & 00015 & 0,00025 & 0.0024 & 0.0016 & 0,0010 & 0.0021 \\
\hline Specticheat $(0 / \mathrm{kg} / \mathrm{K})$ & 832 & 735 & 815 & 700 & 815 & 870 & SBS & 784 & 824 & 812 \\
\hline Specifichest $(\mathrm{cal} / \mathrm{B} / \mathrm{C})$ & 0,20 & 0.18 & 0.19 & 0.18 & Q19 & 0.21 & 0.14 & 0.19 & 0.20 & 0.19 \\
\hline Radiogenic heat $\left(\mu \mathrm{W} / \mathrm{m}^{2}\right)$ & 133 & 105 & 063 & 0,43 & 0.45 & 0.45 & 0.09 & 113 & 0.92 & 0.90 \\
\hline
\end{tabular}

Gretner, 1981

Moddletori, 1993
Waples \& Waples, 2004

Sekiguchl 1944

Pasquale et al, 2011

Peiquale et al 2012 

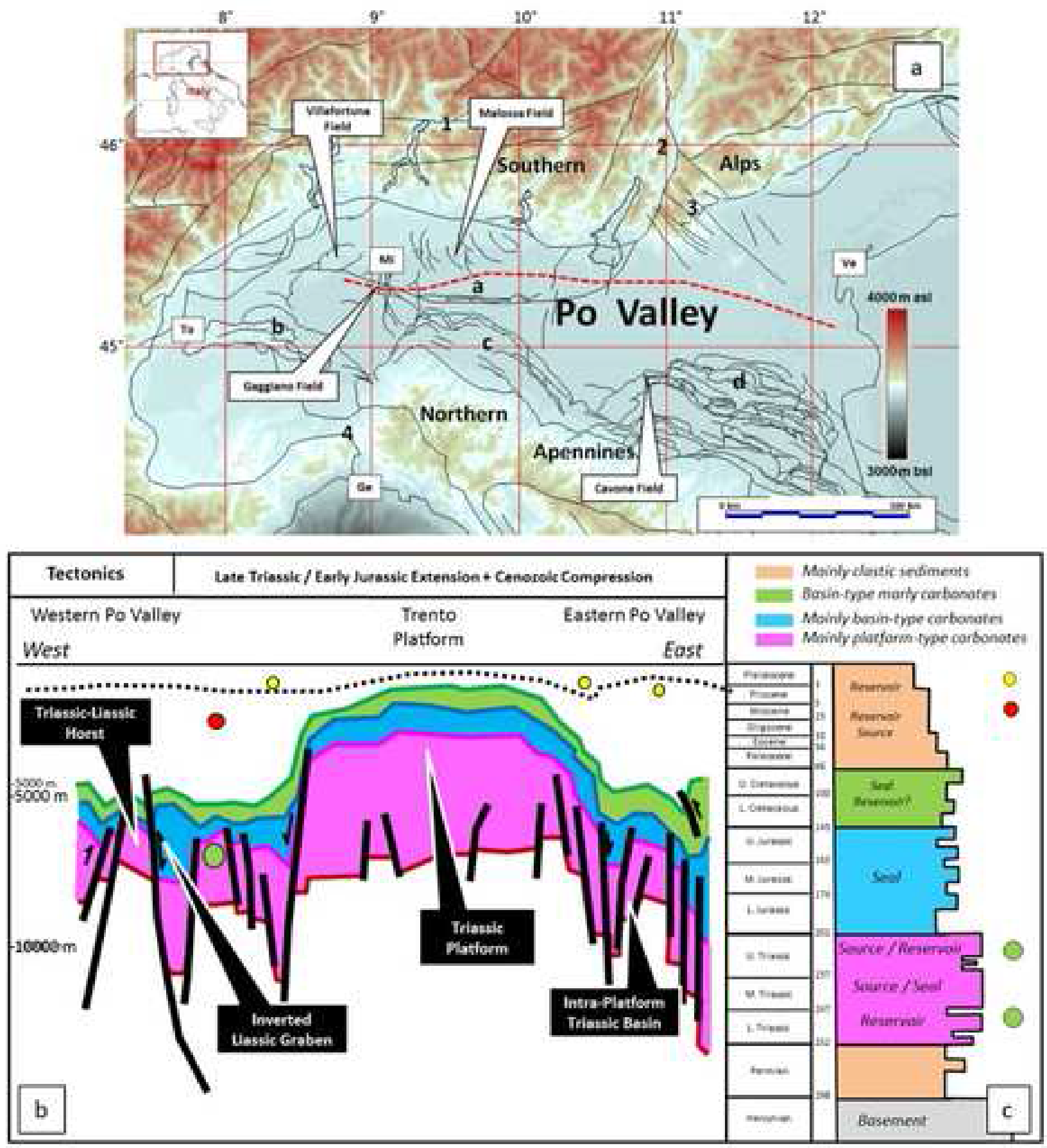


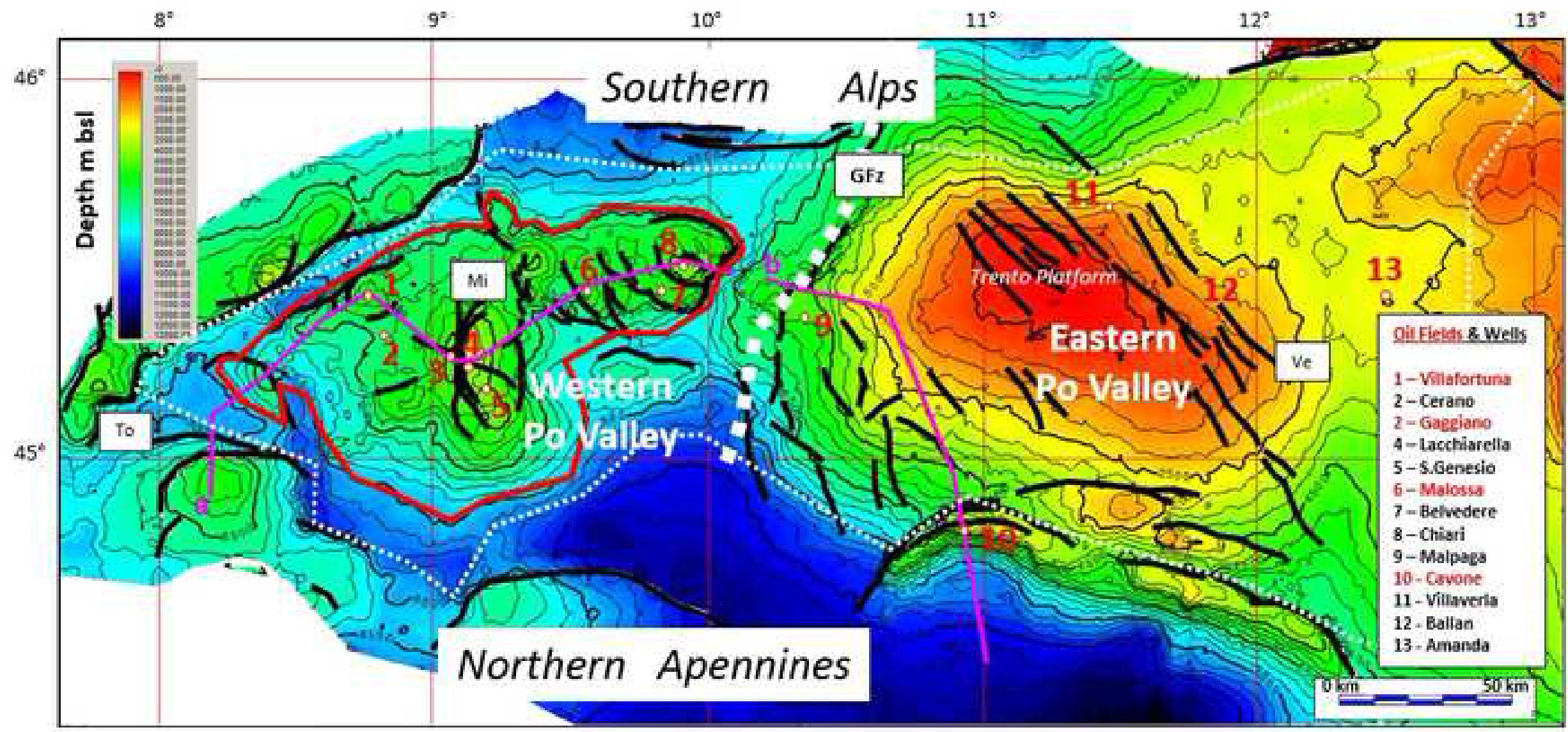


West Monferrato
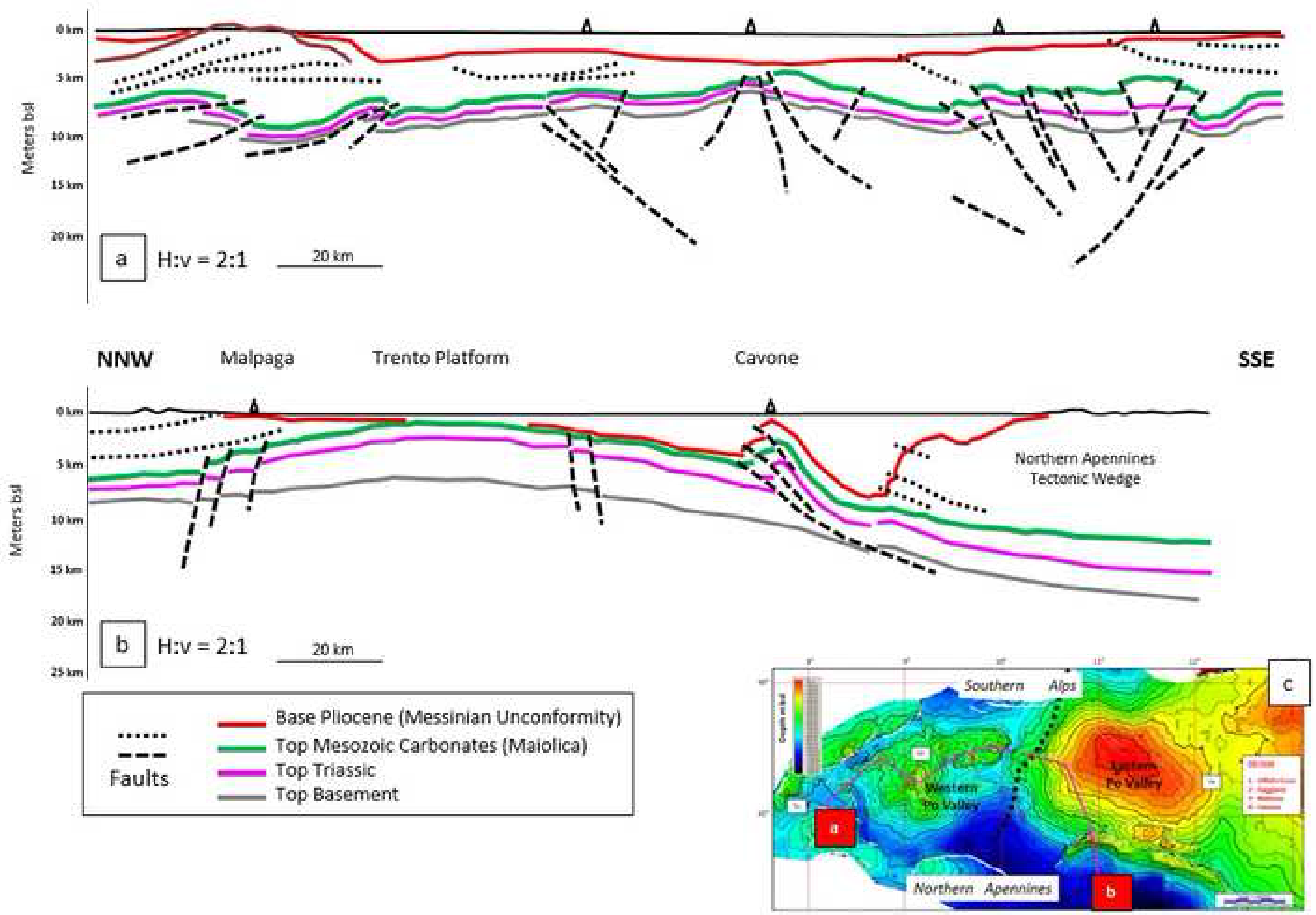


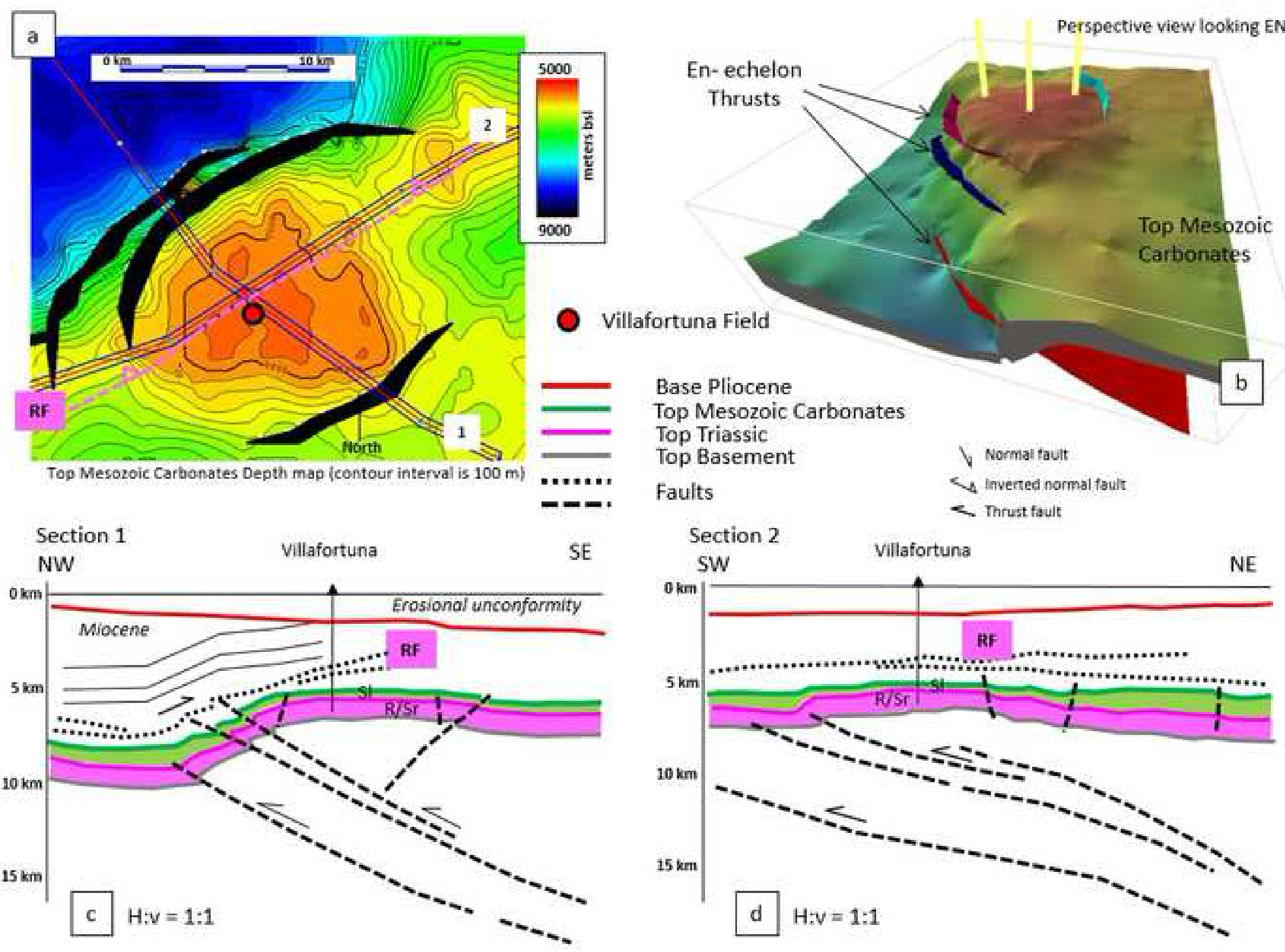




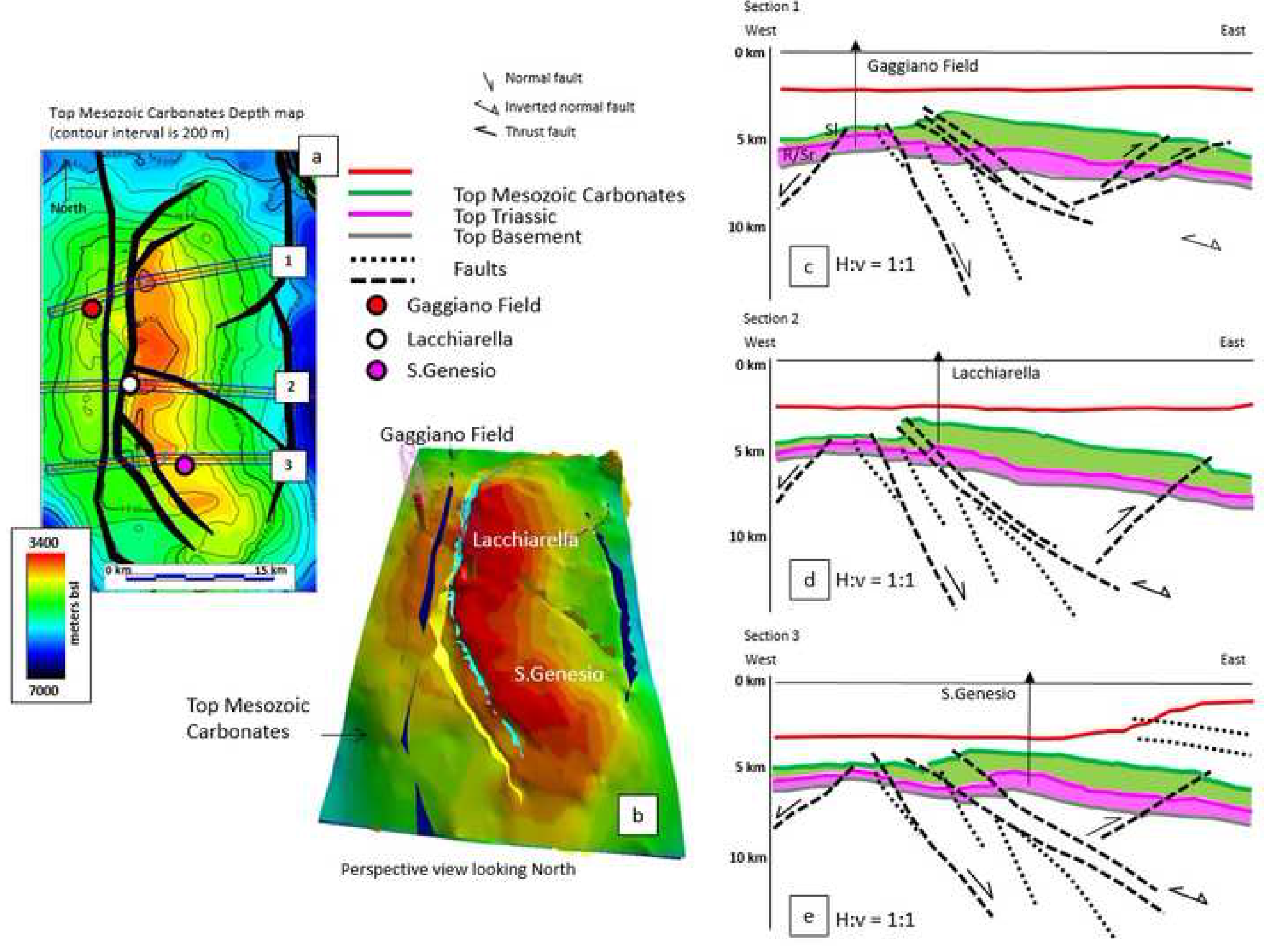




\begin{tabular}{|c|c|c|c|c|}
\hline 4000 & $\bar{Z}$ & $\begin{array}{l}\text { Base Plic } \\
\text { Top Mes } \\
\text { Top Trias } \\
\text { Top Base }\end{array}$ & $\begin{array}{l}\text { ic } \\
\text { icar } \\
\text { nt }\end{array}$ & bonates \\
\hline & $\begin{array}{c}\cdots \\
0\end{array}$ & $\begin{array}{l}\text { Faults } \\
\text { ossa Field }\end{array}$ & $\begin{array}{l}0 \\
0\end{array}$ & $\begin{array}{l}\text { Belvedere } \\
\text { Chiari }\end{array}$ \\
\hline
\end{tabular}
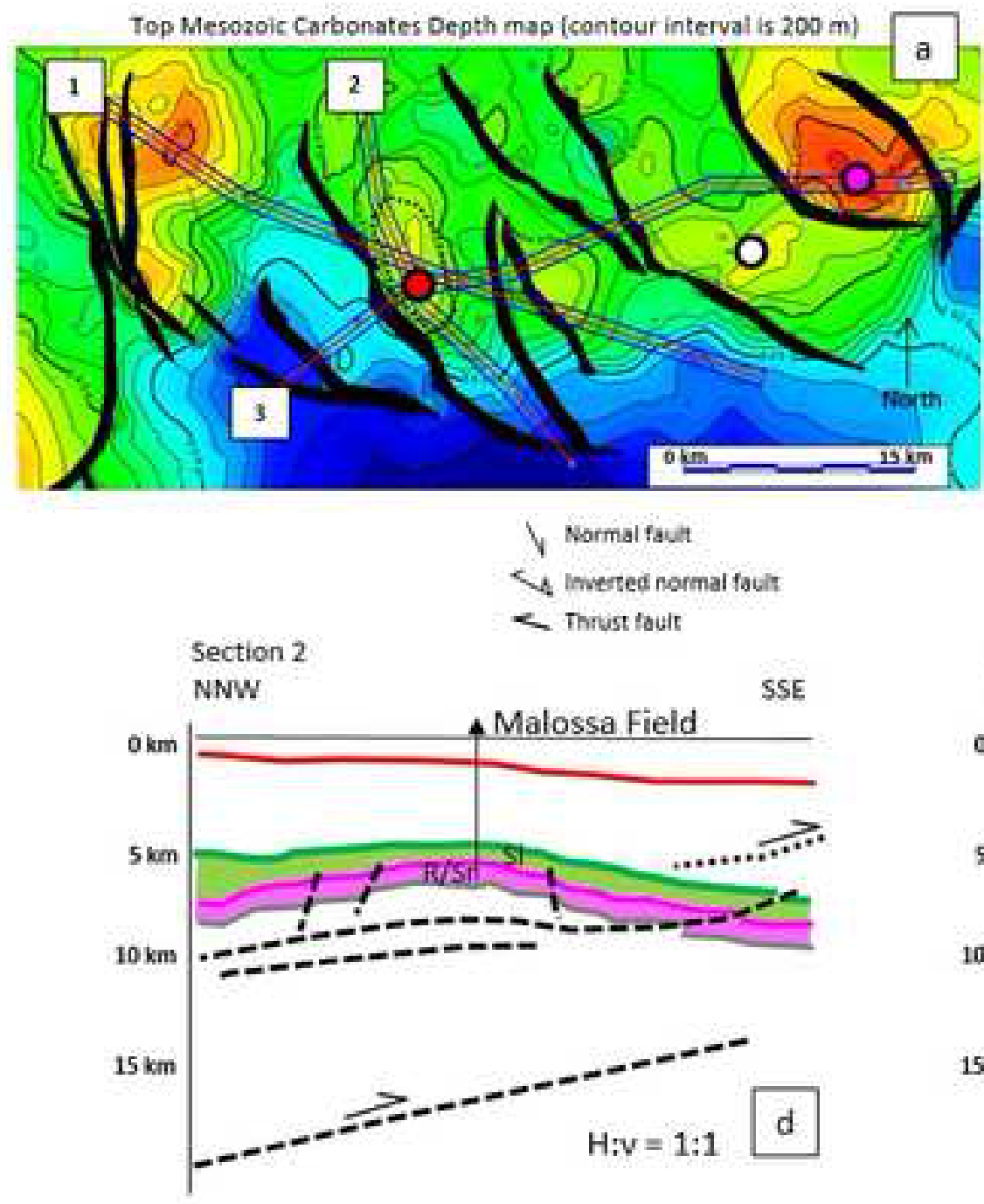
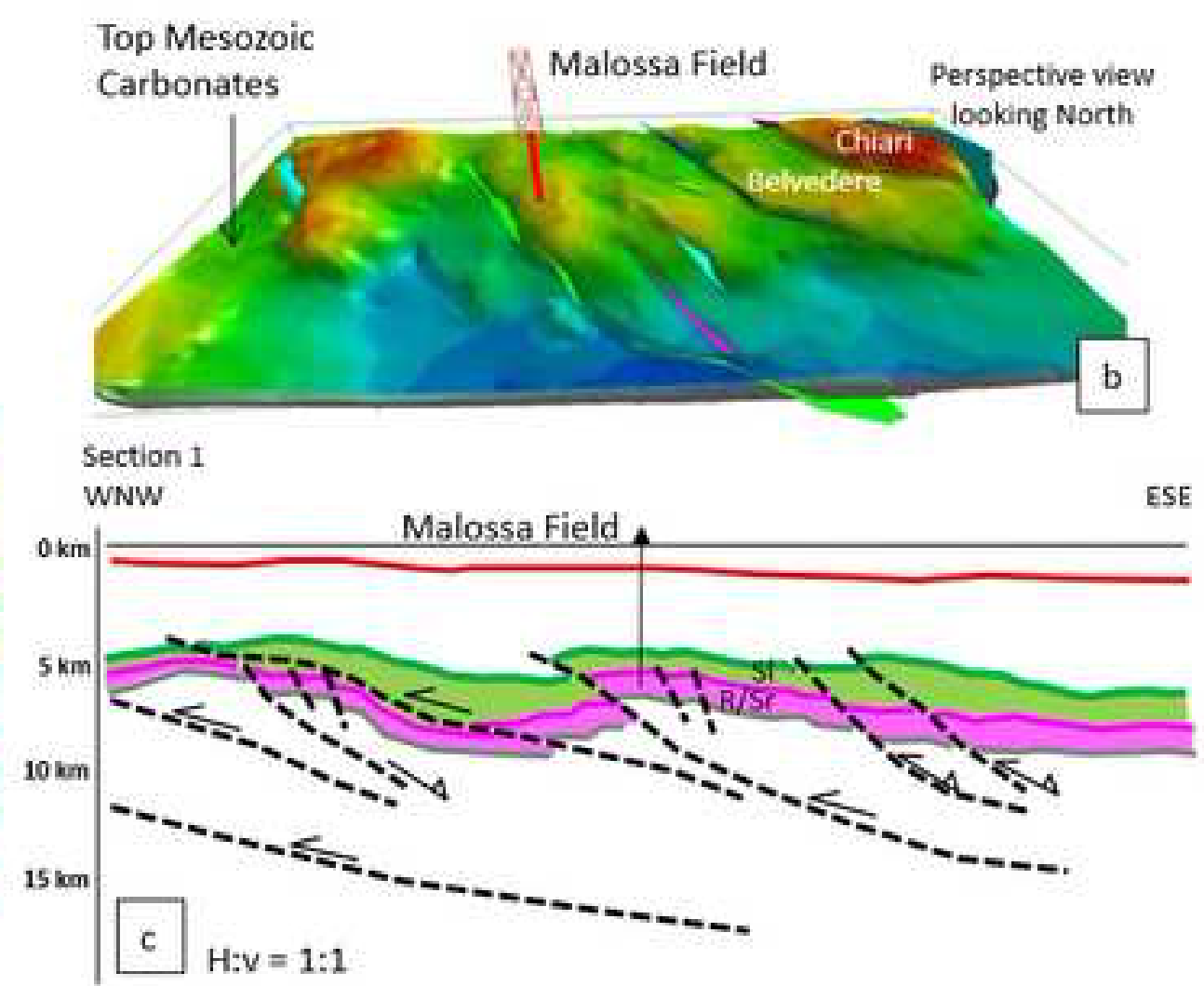

Section 3

wsw

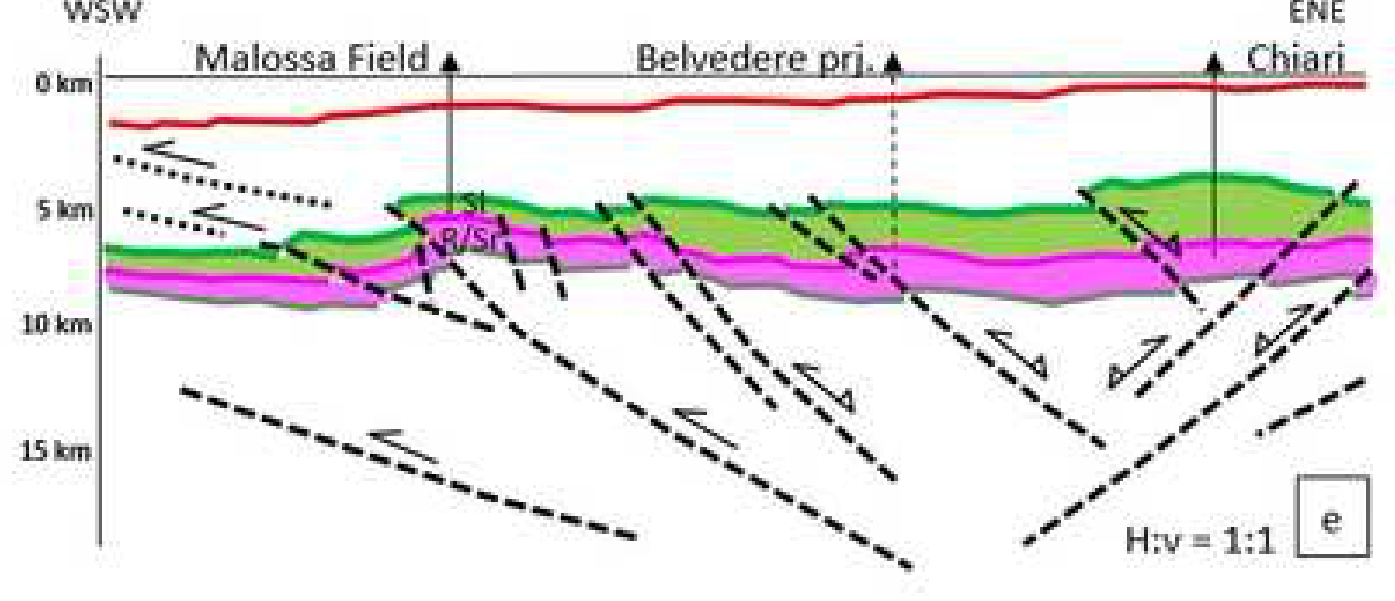


Top Mesozoic Carbonates Depth map (contour interval is $500 \mathrm{~m}$ )

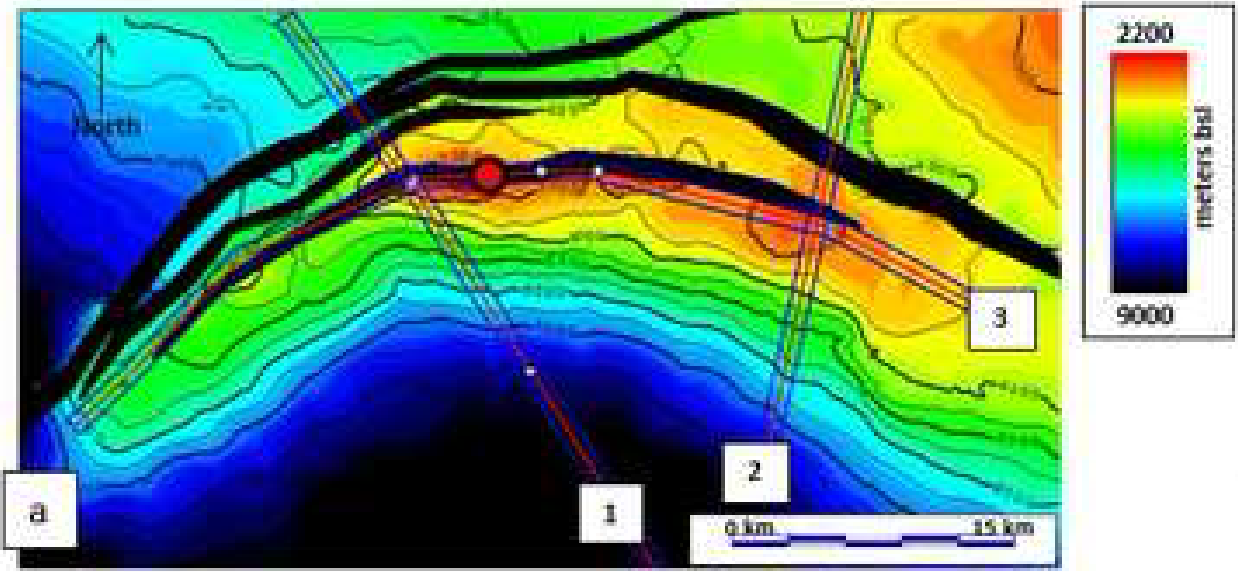

Section 1

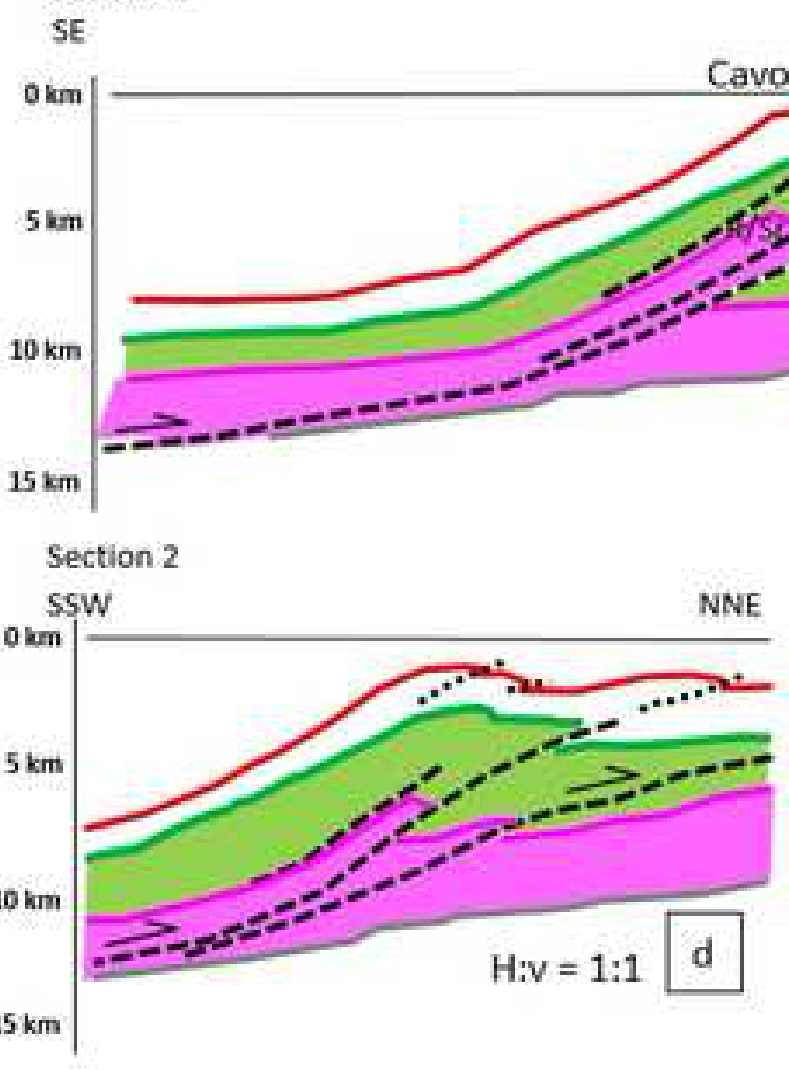

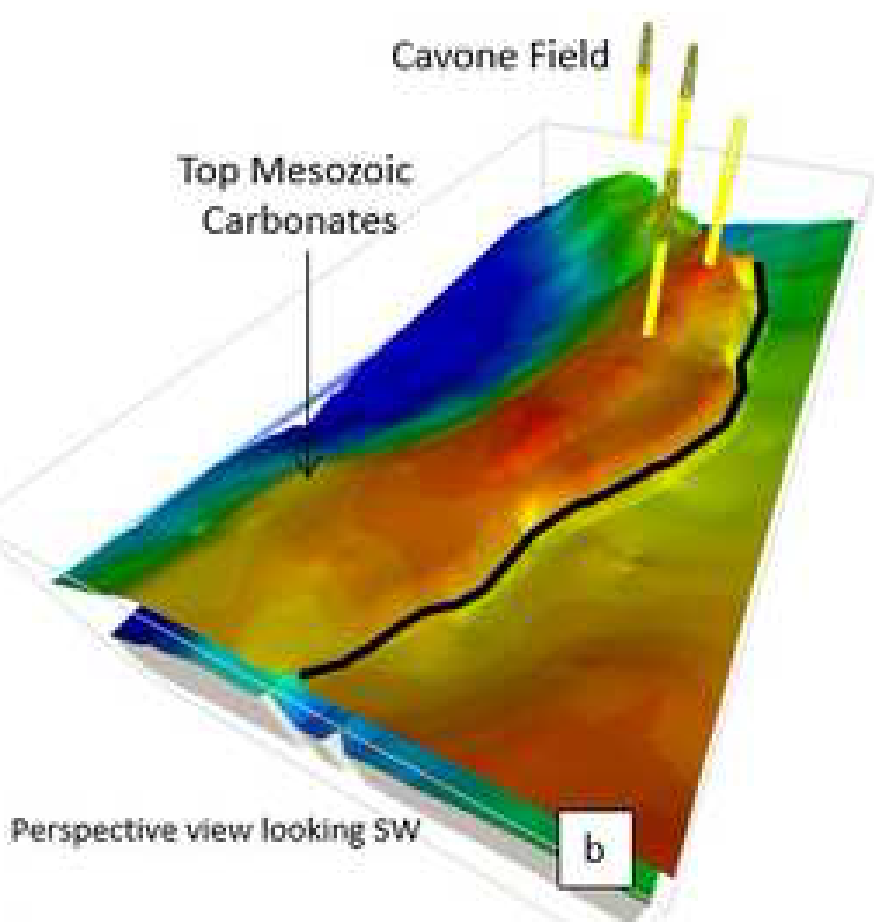

- Cavone Field

Base Pliocene

- Top Mesozoic Carbonates

- Top Triassic

Top Basement

- Faults
Cavone Field

East

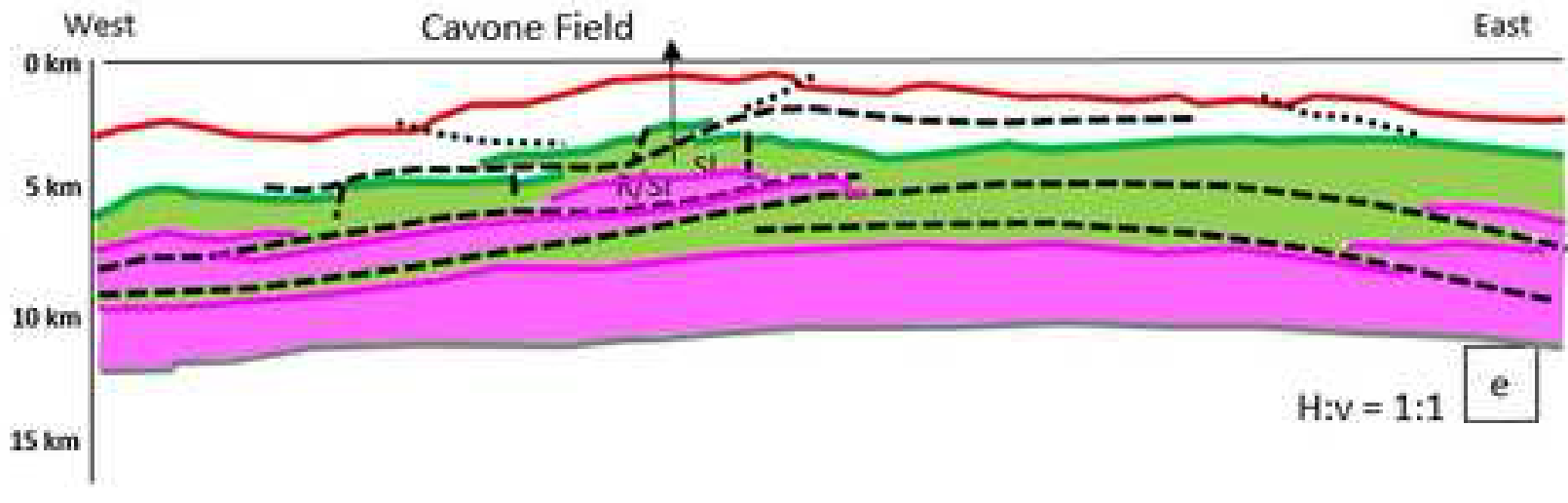



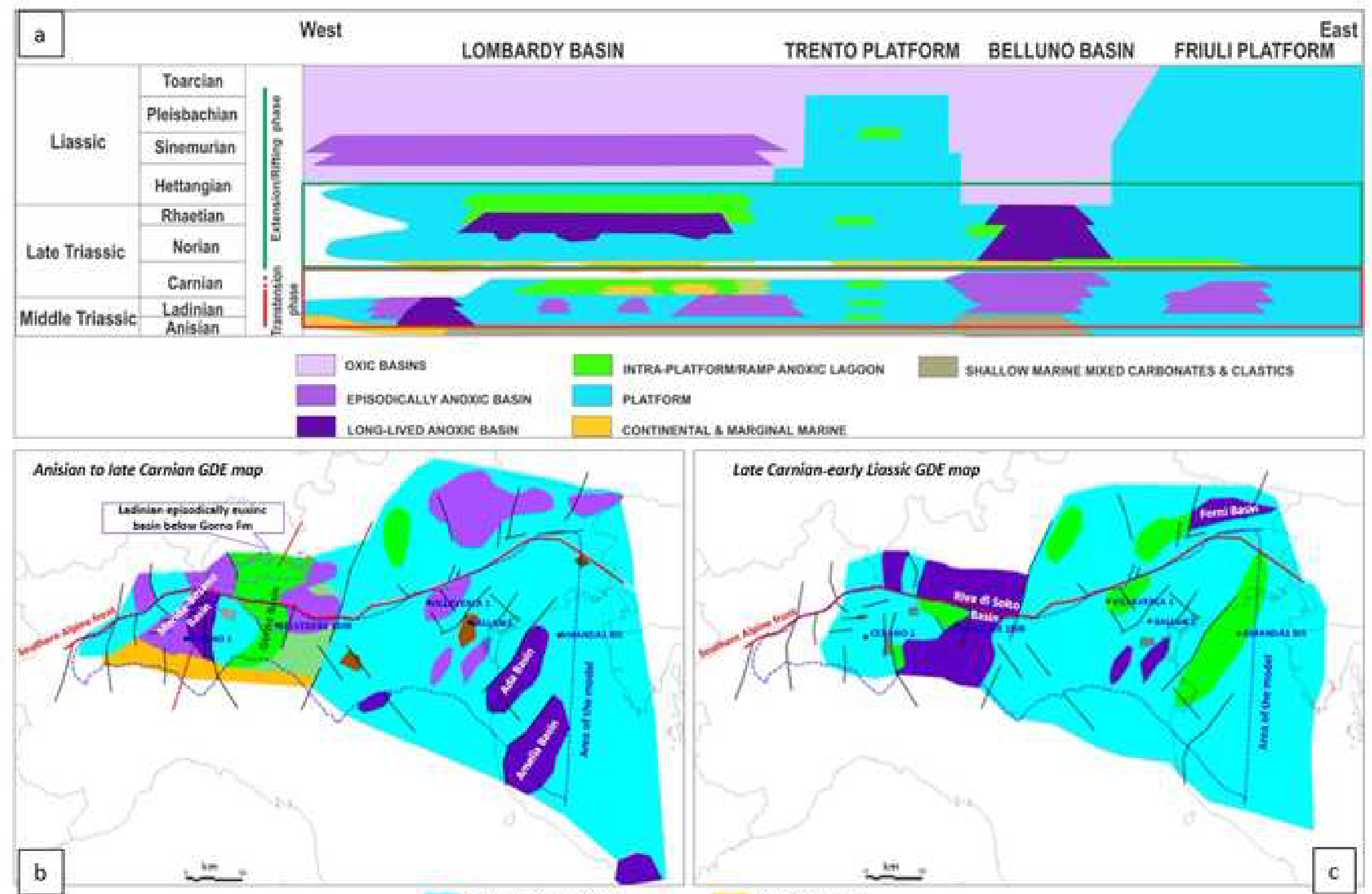

Dallow water carbonates

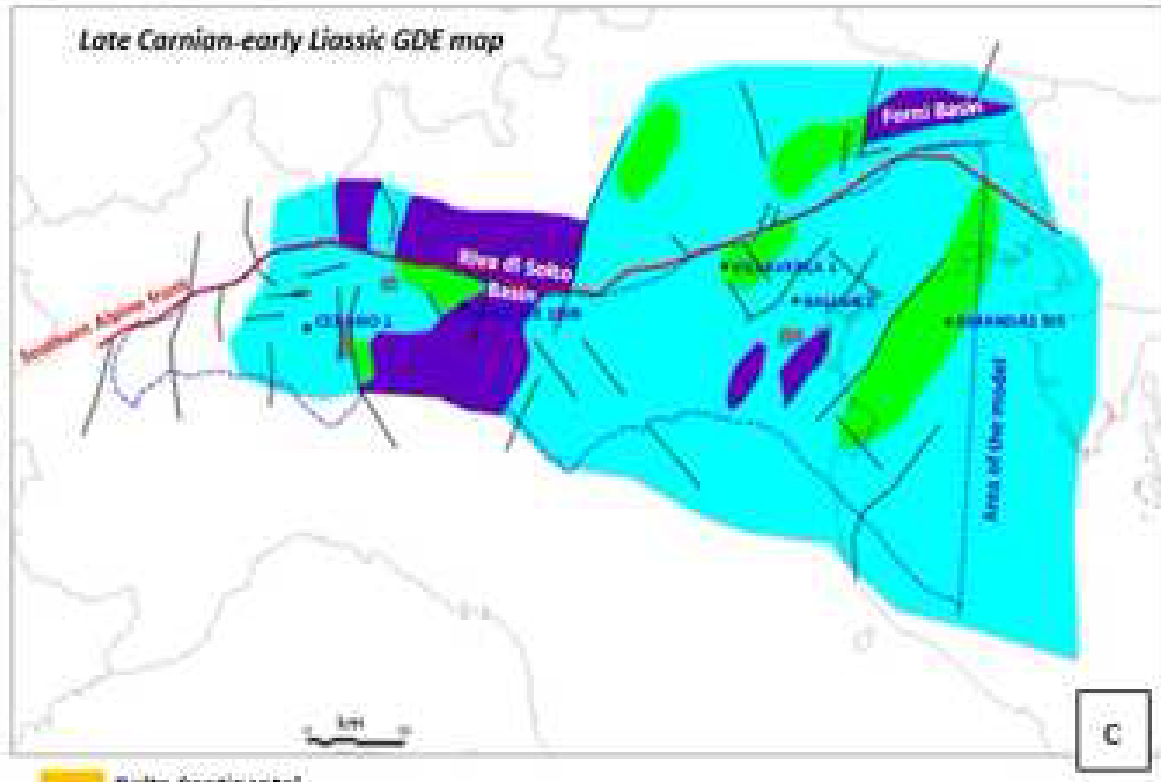

Detta Continental

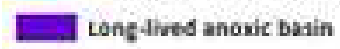

tphedicalily anoxix bain

II

Intra-plaffeem/ramp unexic laposa

ugneour

El temerged areas 
(a) Litho-stratigraphy

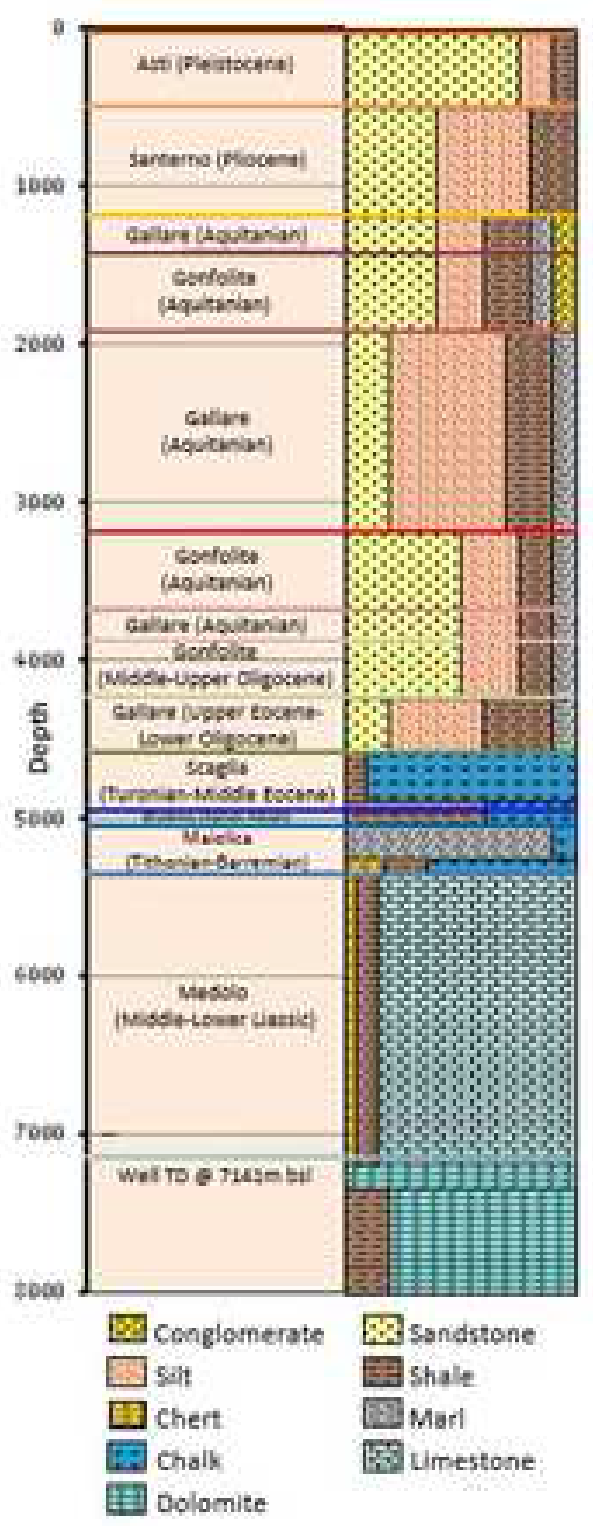

(b) Formation Pressure (psi)

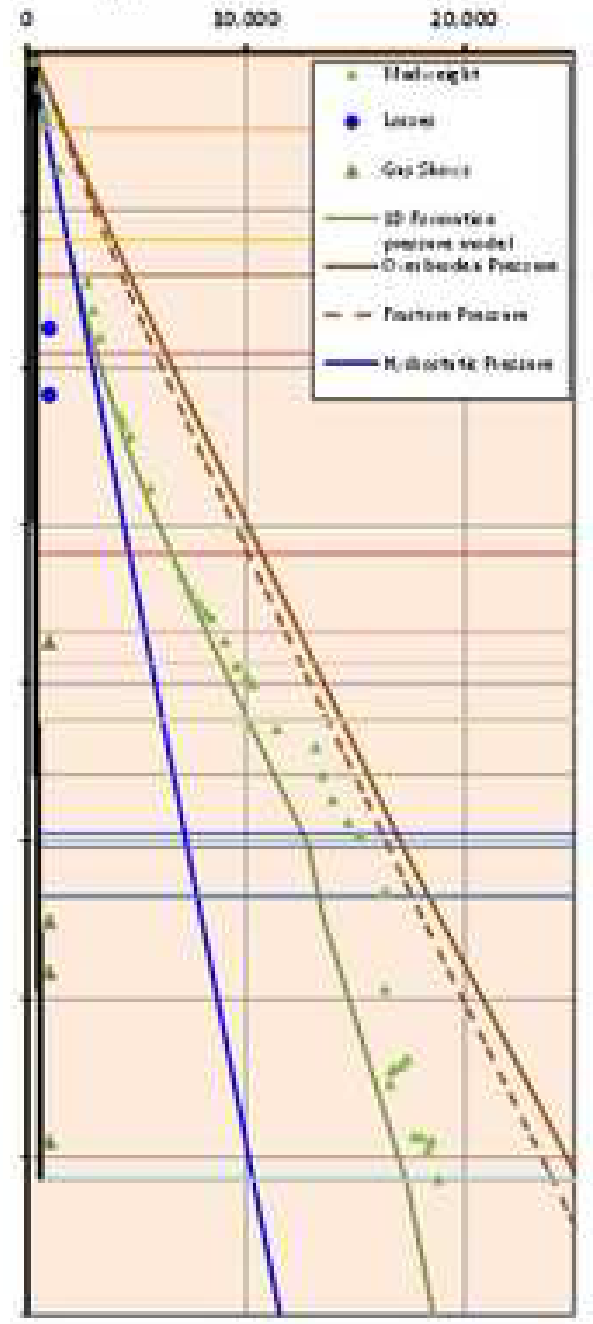

(d) Thermal Maturity $\left(\mathrm{QR}_{\mathrm{Q}}\right)$

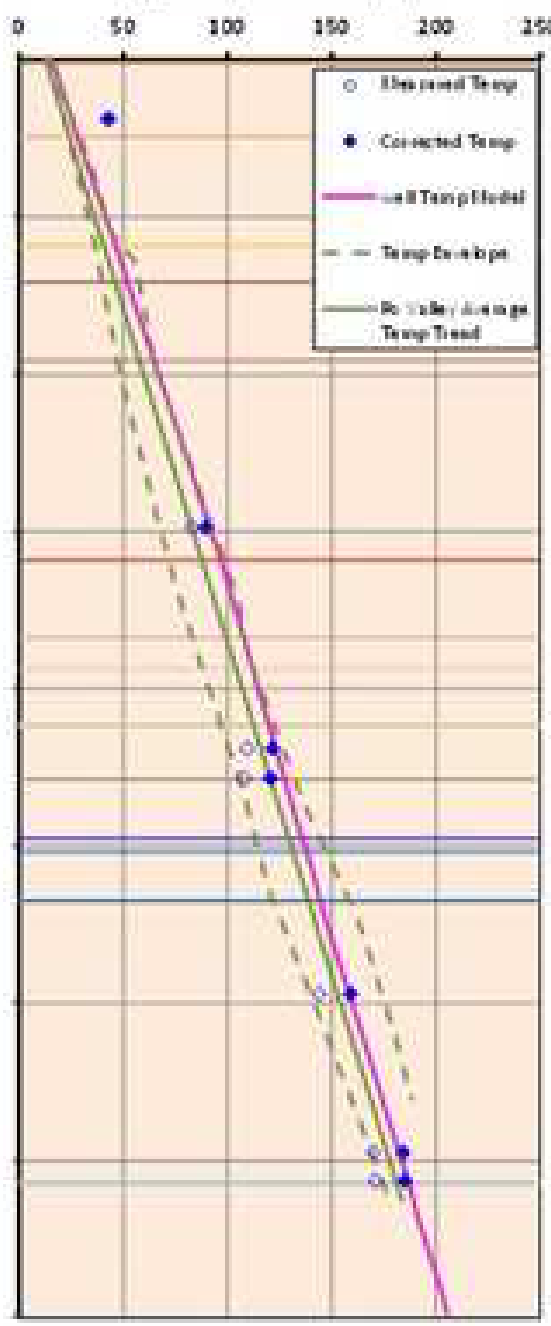

20

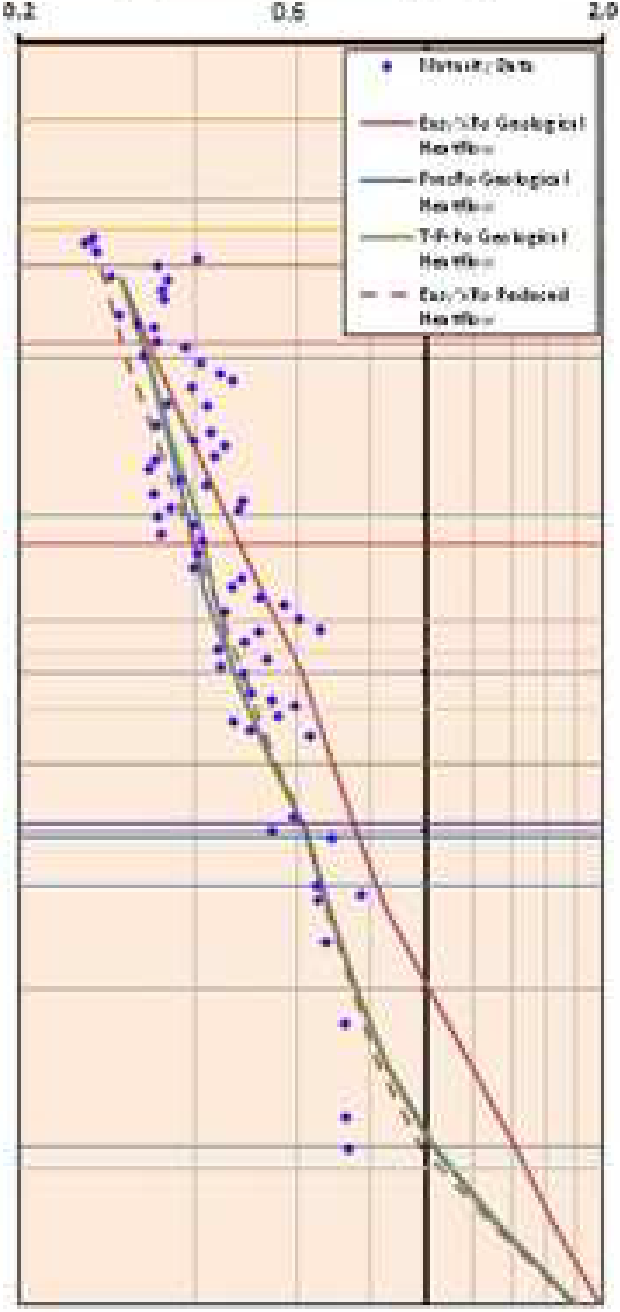




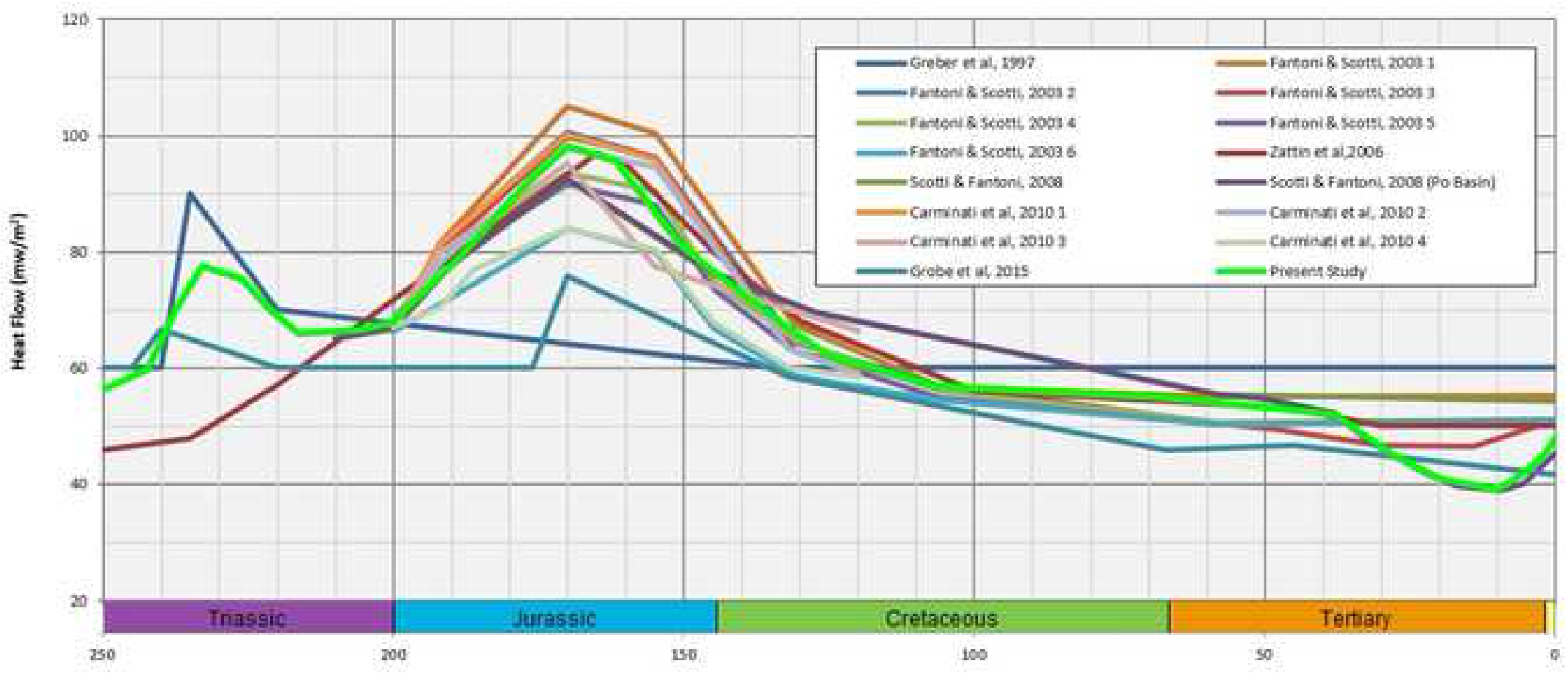



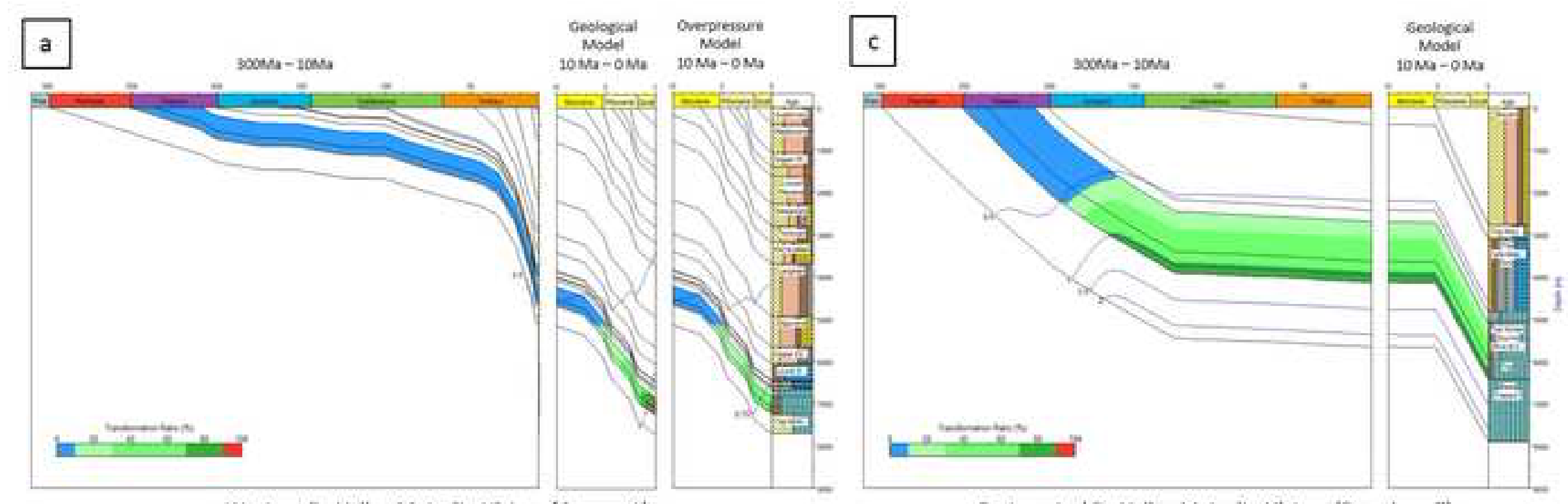

\section{b}

Western Po Valley Maturity History (Cerano-1)

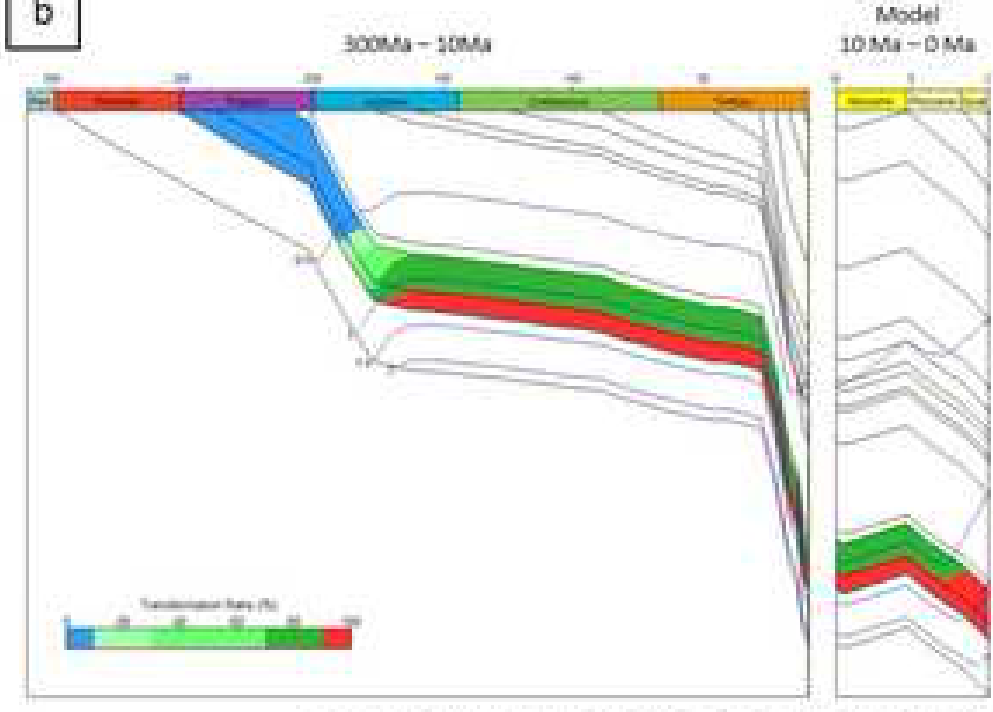

Central Po Valley Maturity History (Belvedere-1)

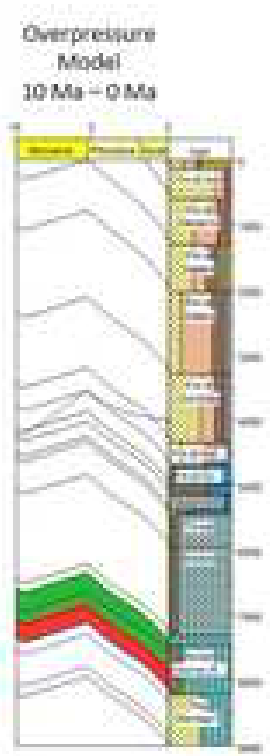

Eastern Po Valley Maturity History (Ballan-1)

Geological $10 \mathrm{Ma}-0 \mathrm{Na}$

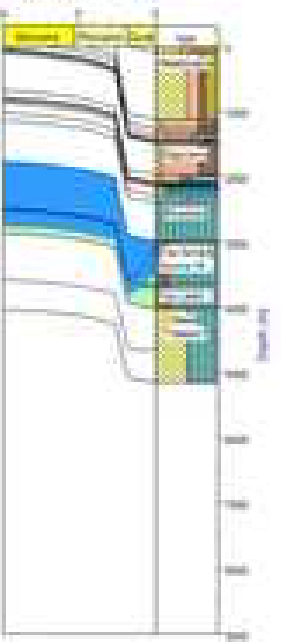




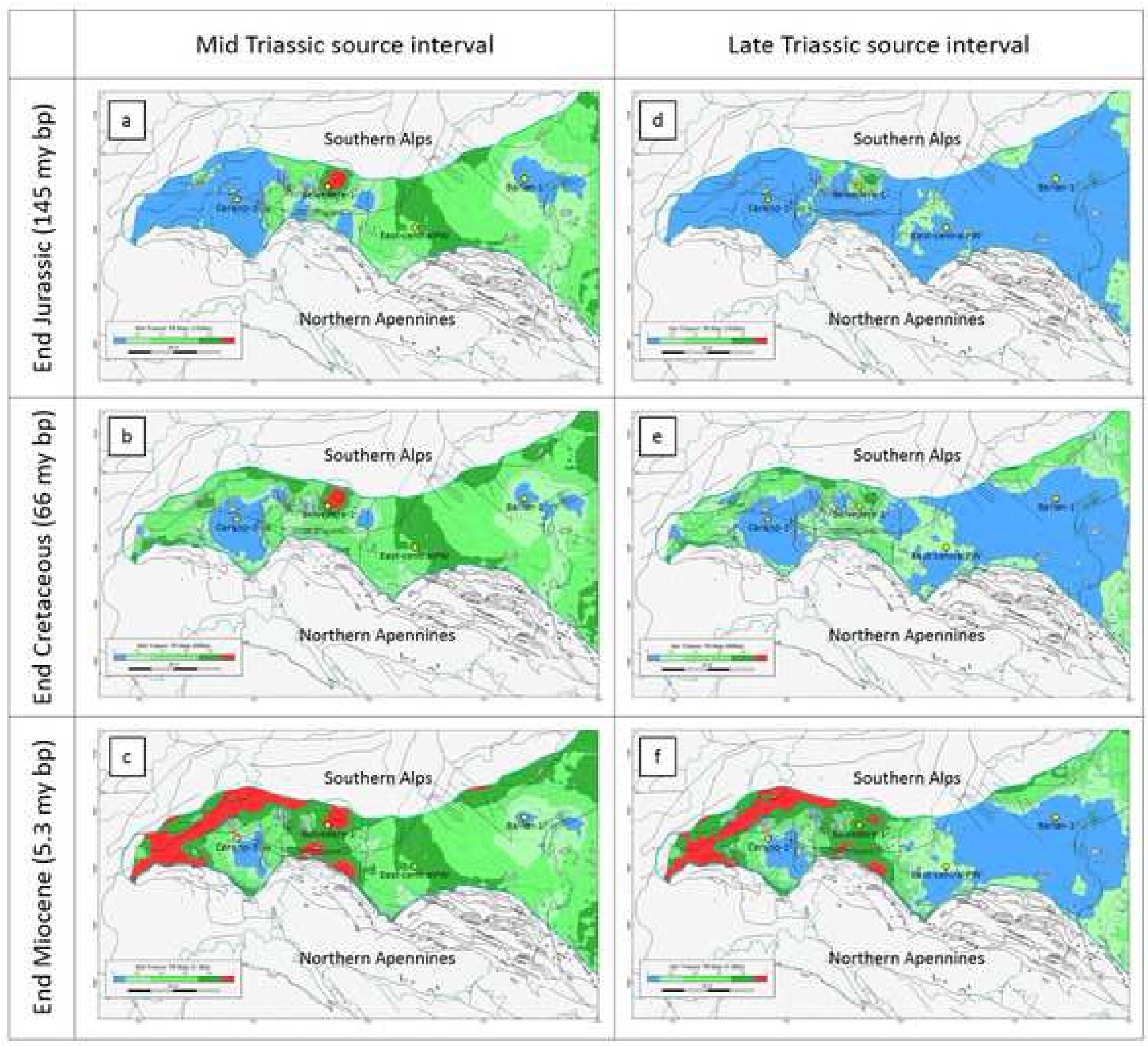




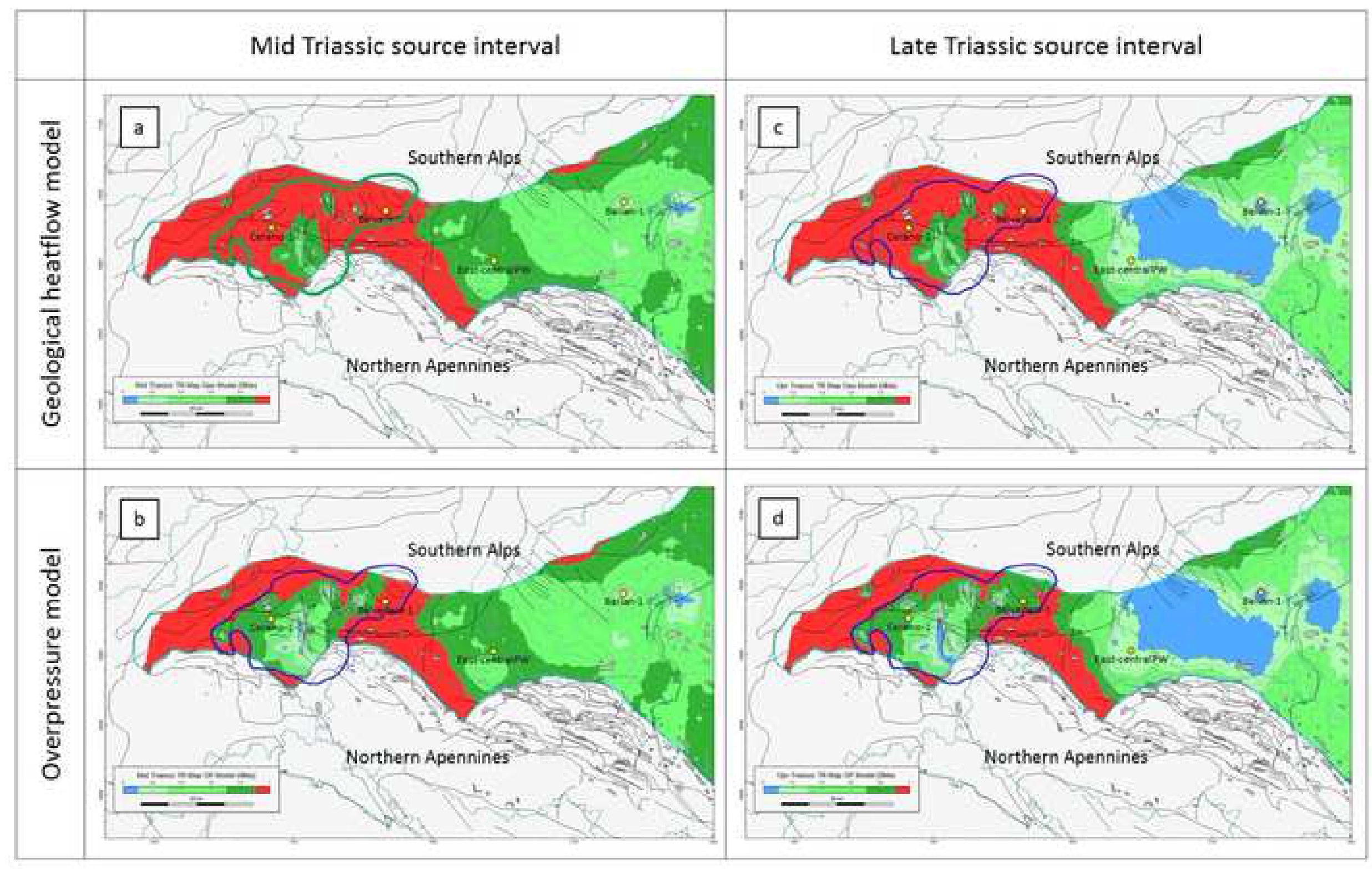


Fig. 14

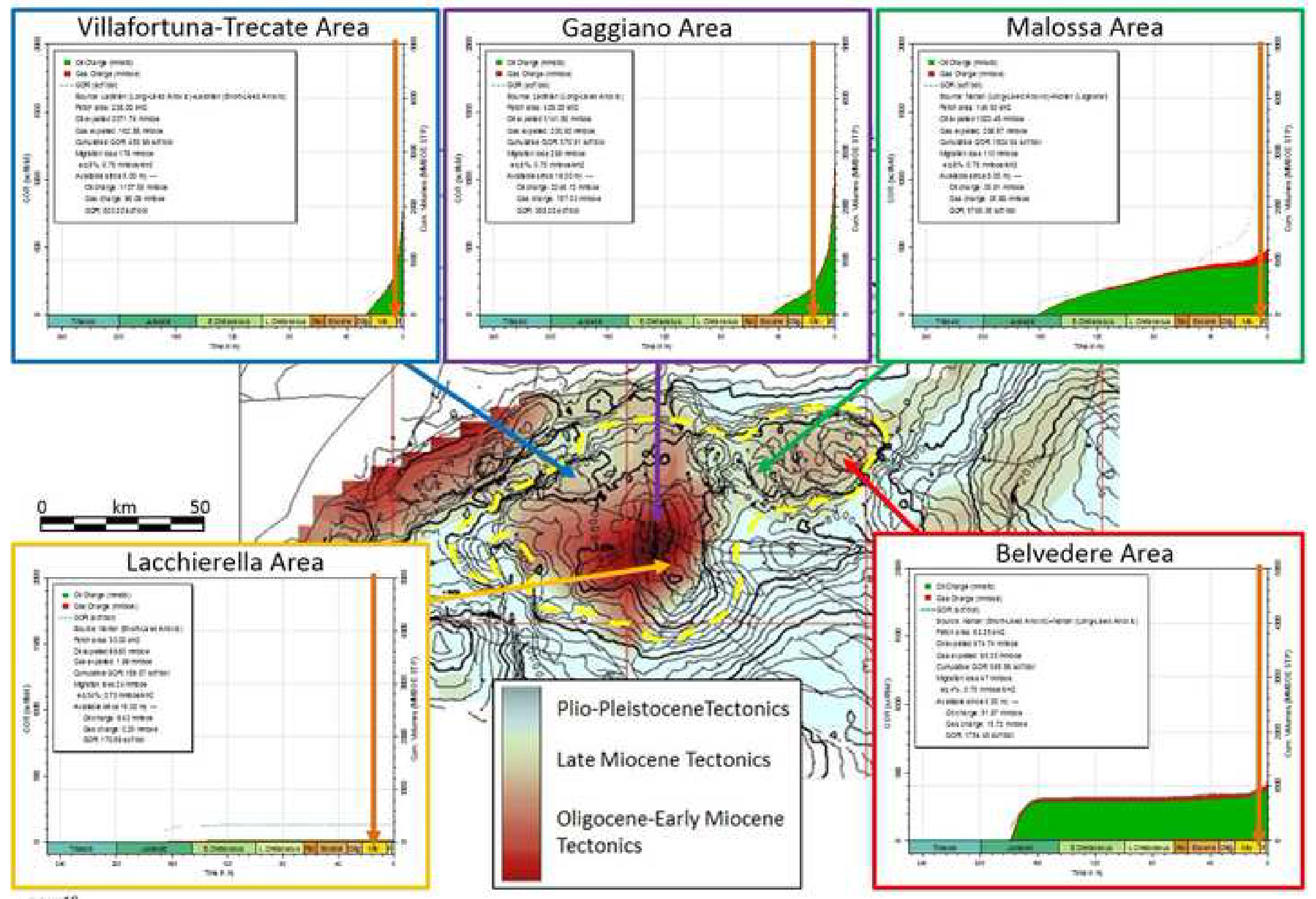



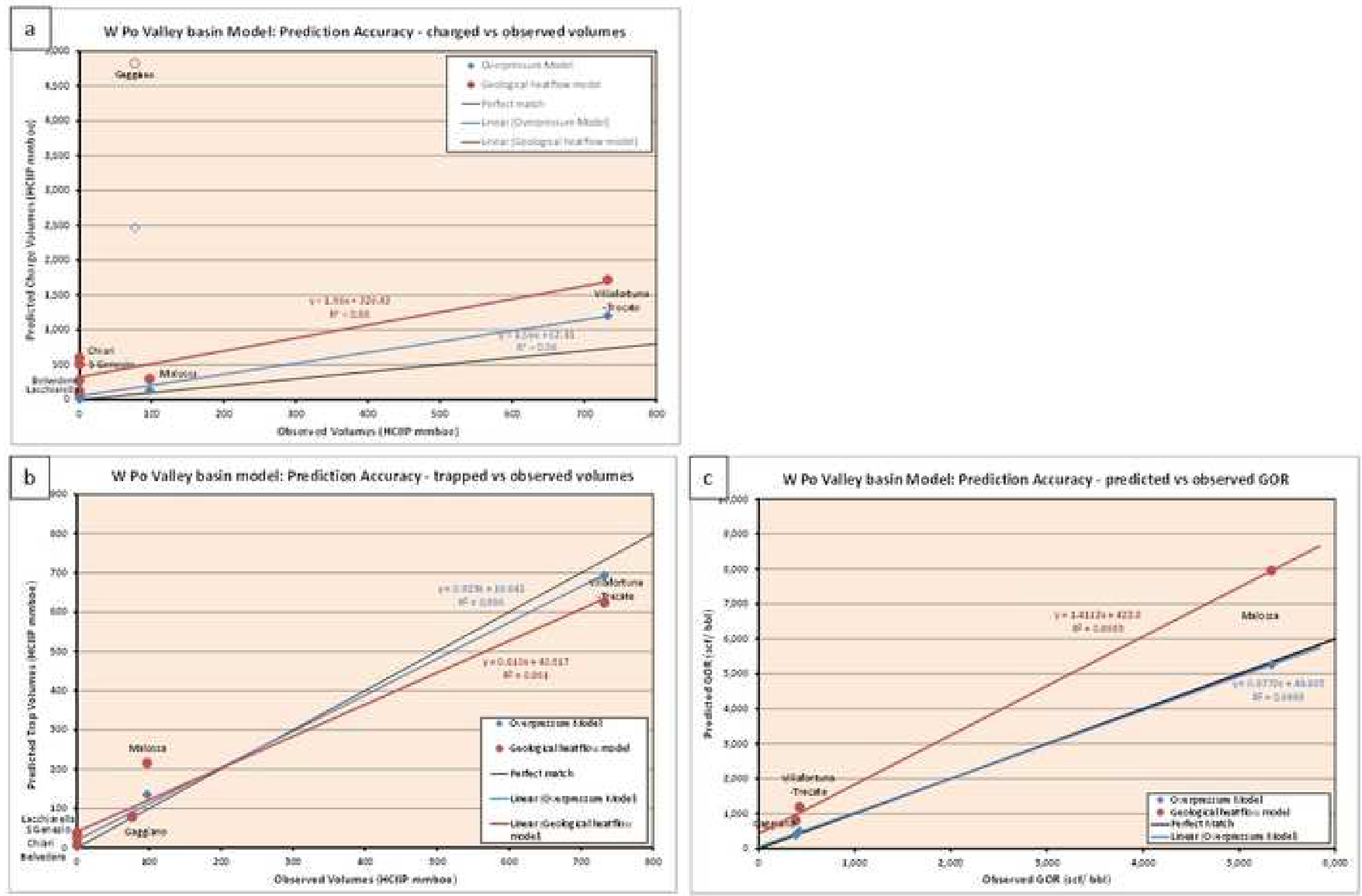